Alone You Are Nobody, Together We Float: The Manuela Ramos Movement
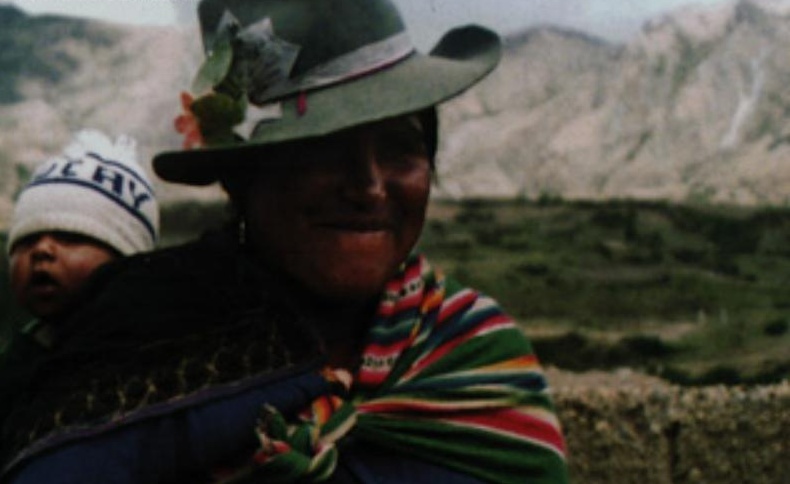

t.
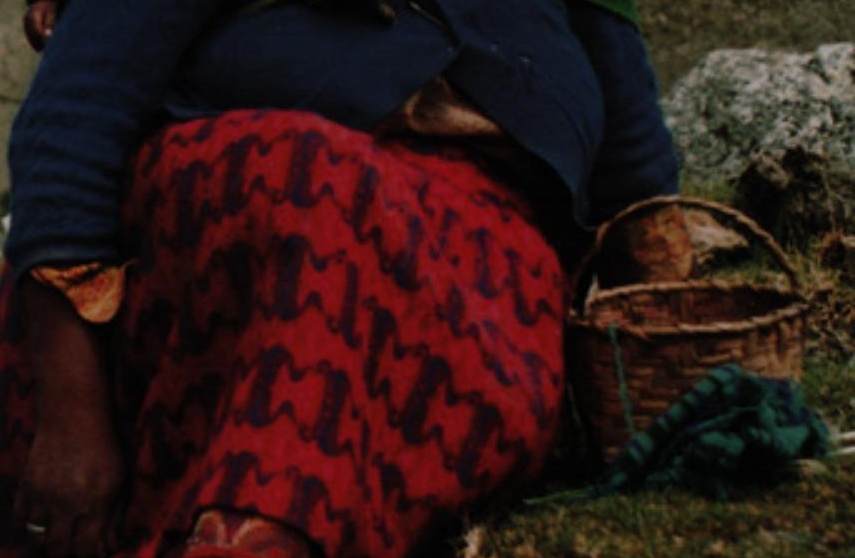

'é/Quality/Calidad/Qualité/6 
Quality/Calidad/Qualité, a publication of the Population Council, highlights examples of family planning and reproductive health programs that are providing unusually high quality care. This series is part of the Council's Robert H. Ebert Program on Critical Issues in Reproductive Health which, through scientific and practical efforts, seeks to improve and expand the scope and quality of reproductive health care. The philosophical foundation of the program, and of this series, is that women and their partners have a fundamental right to respectful treatment, information, choice, and follow-up from reproductive health care providers. The pamphlets reflect one of the four main thrusts of the program: enhancing the quality of family planning programs.

Projects are selected for documentation in the Quality/Calidad/Qualité series by an Advisory Group made up of individuals who have a broad range of experience within the field of reproductive health and are committed to improving the quality of services. These projects are making important strides in one or more of the following ways: broadening the choice of contraceptive methods and technologies available; providing the information clients need to make informed choices and better manage their own health care; strengthening the quality of client/provider interaction and encouraging continued contact between providers and clients; making innovative efforts to increase the management capacity and broaden the skills of service providers at all levels; expanding the constellation of services and information provided beyond those conventionally defined as "family planning"; and reaching underserved and disadvantaged groups with reproductive health care services.

None of the projects documented in the series is being offered as a model for replication. Rather, each is presented as an unusually creative example of values, objectives, and implementation. These are "learning experiences" that demonstrate the self-critical attitude required to anticipate clients' needs and find affordable means to meet them. This reflective posture is exemplified by a willingness to respond to changes in clients' needs as well as to the broader social and economic transformations affecting societies. Documenting the critical choices these programs have made should help to reinforce, in practical terms, the belief that an individual's satisfaction with reproductive health care services is strongly related to the achievement of broader health and population goals.

Publication of this edition of Quality/Calidad/Qualité is made possible by support provided by the Ford Foundation, the John D. and Catherine T. MacArthur Foundation, and the Population Council.

Statements made and views expressed in this publication are solely the responsibility of the authors and not of any organization providing support for Quality/Calidad/Qualité. Any part of this document may be reproduced without permission of the authors so long as it is not sold for profit.

\section{(P) Population Council}

The Population Council is an international, nonprofit, nongovernmental institution that seeks to improve the wellbeing and reproductive health of current and future generations around the world and to help achieve a humane, equitable, and sustainable balance between people and resources. The Council conducts biomedical, social science, and public health research and helps build research capacities in developing countries. Established in 1952, the Council is governed by an international board of trustees. Its New York headquarters supports a global network of regional and country offices.

Population Council, One Dag Hammarskjold Plaza, New York, New York 10017 USA

tel: (212) 339-0500, fax: (212) 755-6052, e-mail: pubinfo@popcouncil.org, http://www.popcouncil.org 


\section{About the Authors}

Judith Bruce is a Senior Associate in the International Programs Division of the Population Council in New York.

Debbie Rogow has worked as a Senior Advisor and Researcher in international reproductive health for more than fifteen years. Her collaboration with and assistance to the Manuela Ramos Movement has been on behalf of the International Women's Health Coalition, USAID/Pop Tech, Futures, and the Population Council.

\section{Quality/Calidad/Qualité Advisory Group}

$\begin{array}{llll}\text { Ian Askew } & \text { Nicole Haberland } & \text { Elizabeth McGrory } & \text { Jill Sheffield } \\ \text { Karen Beattie } & \text { Joan Haffey } & \text { Kirsten Moore } & \text { Cynthia Steele } \\ \text { Martha Brady } & \text { Judith Helzner } & \text { Nancy Newton } & \text { Nahid Toubia } \\ \text { George Brown } & \text { Kathleen Kurz } & \text { John Paxman } & \text { Gilberte Vanintejan } \\ \text { Judith Bruce } & \text { Ann Leonard } & \text { Julie Reich } & \text { Beverly Winikoff } \\ \text { Adrienne Germain } & \text { Magaly Marques } & \text { Debbie Rogow } & \end{array}$

Photography:

Printing:

Editorial and Production

Coordination:

\author{
Debbie Rogow and ReproSalud \\ Graphic Impressions
}

diane rubino

\section{Quality/Calidad/Qualité Booklets Currently Available}

Celebrating Mother and Child on the Fortieth Day: The Sfax Tunisia Postpartum Program by Francine Coeytaux, Introduction and Afterword by Beverly Winikoff, 1989. (Available in English; text in Spanish and French available in typewritten format)

Man/Hombre/Homme: Meeting Male Reproductive Health Care Needs in Latin America by Debbie Rogow, Introduction and Afterword by Judith Bruce and Ann Leonard, 1990. (Available in English and Spanish)

Gente Joven/Young People: A Dialogue on Sexuality with Adolescents in Mexico by Magaly Marques, Introduction by John M. Paxman and Afterword by Judith Bruce, 1993. (Available in English and Spanish)

The Coletivo: A Feminist Sexuality and Health Collective in Brazil by Margarita Díaz and Debbie Rogow, Introduction by José Barzelatto, 1995. (Available in English and Portuguese)

Doing More with Less: The Marie Stopes Clinics of Sierra Leone by Nahid Toubia, Introduction by Grace Eban Delano, 1995. (Available in English)

Introducing Sexuality within Family Planning: The Experience of Three HIV/STD Prevention Projects from Latin America and the Caribbean by Julie Becker and Elizabeth Leitman, Introduction by Mahmoud F. Fathalla, 1997. (Available in English and Spanish)

Using COPE to Improve Quality of Care: The Experience of the Family Planning Association of Kenya by Janet Bradley, Introduction by Judith Bruce, Soledad Diaz, and Carlos Huezo, Afterword by Kalimi Mworia, 1998. (Available in English and Spanish)

(Each English edition contains a one-page summary in both French and Spanish.)

We invite your comments and ideas for projects that might be included in future editions of Quality/Calidad/Qualité. If you would like to be included on our mailing list, please write to Quality/Calidad/Qualité, Population Council, One Dag Hammarskjold Plaza, New York, NY 10017 USA, or e-mail pubinfo@popcouncil.org 


\title{
Alone You Are Nobody, Together We Float: The Manuela Ramos Movement
}

\author{
by Debbie Rogow \\ Introduction and Afterword by Judith Bruce
}

\section{Introduction}

Since population programs were first articulated in the late 1960s and early 1970s, the emphasis has been on the delivery of contraceptive services, with some lesser attention given to safe motherhood and child survival. Almost no programmatic attention has been paid to related reproductive health issues such as reproductive tract infections (RTIs), sexual violence, and unwanted pregnancy. In addition, family planning programs have virtually ignored the substantial underlying social barriers that restrict women's access to service and choice, such as limited negotiating power in sexual relationships, social isolation, domestic violence, and lack of cash resources.

Founded on the premise that access is the key issue, traditional population programs embraced a "supply-side" paradigm: Make family planning services available and people will use them. Family planning programs evolved vertically for the distribution of contraceptives through three parallel systems: clinical outlets, community-based distributors, and commercial/social marketing. This supply-side approach has also been closely linked to technology, with new program directions often catalyzed around technological development (e.g., the sudden availability of a new vasectomy technique). Therefore, the skills providers were thought to need were mainly clinical, and issues of quality and effectiveness of services rested on fairly standard but limited parameters of provider competence. The expectation was that after a standard start-up phase of several years, services would be "in place," and the results (typically measured by number of contraceptives dispensed) would come quite rapidly.

Several decades later, research has shown that the success of this approach has been uneven in most countries, including Peru, the setting of this issue of Quality/Calidad/Qualité. For although contraceptive prevalence has reached over 64 percent among married women in Peru, much (36 percent) of this "use" is of "traditional methods" - such as rhythm and withdrawal — which have not been given active support by the majority of family planning programs. ${ }^{1}$ In addition, it is estimated that one-third of all pregnancies in Peru end in abortion (WHO 1998, p. 56). Further, up to 60 percent of all pregnancies may be unwanted, in the sense that the timing is wrong or the pregnancy takes the individual or couple beyond their desired family size, indicating a significant gap between desired and achieved family size (having more children than originally envisioned). Thus, among poor women in particular, there remains substantial unmet need for family planning services.

\footnotetext{
${ }^{1}$ Of the 16,885 married women interviewed in the 1996 DHS survey, 10,840 (64 percent) reported contraceptive use. Among these women using contraceptives, 3,867 (36 percent) reported use of a "traditional" method and 6,974 (64 percent) reported use of a "modern" method (Moyano et al. 1997, p. 63).
} 
The narrow emphasis on contraceptive delivery is also linked to neglect of other essential aspects of reproductive health. For example, obstetrical services that were once offered without charge now require cash payments for supplies, which forces many poor women to forsake a hospital delivery. Further, only 7 percent of women in Peru have ever had a Pap smear.

During the same period in which the Peruvian population and family planning initiatives were evolving, the Manuela Ramos Movement was also coming of age and developing its own view of the reproductive health needs of women. Beginning in the late 1970s as a small, feminist, urban nongovernmental organization (NGO), the Manuelas embraced a very different philosophy that viewed contraception as only one element within a larger constellation of women's reproductive health needs. As a result, their clinics routinely offered Pap smears, RTI testing, and counseling. The organization also advocated for decriminalization of abortion based on its experience and understanding of the reproductive health needs of poor women.

Over the past two decades, the Manuela Ramos Movement grew from a Lima-based women's collective into a mature and visionary organization of national standing. It was at this point that its evolution took an unusual turn: The Manuelas entered into an ambitious collaboration with the United States Agency for International Development (USAID) to develop a reproductive health approach appropriate for poor, hard-to-reach women in Peru. This project, to be called ReproSalud, was designed to succeed where traditional programs had failed, by responding to the distinctive social profile of poor women, most of whom reside in remote rural areas. It serves as a natural case study of the principles set forth at the International Conference on Population and Development (ICPD) held in Cairo in 1994. The ICPD Plan of Action defined the goal of service delivery as offering reproductive health and choice to individuals, and identified the empowerment of women as a key strategy for bringing population and resources into balance. In this issue of Quality/Calidad/Qualité, Debbie Rogow explores why the Manuelas were uniquely placed to implement this new approach based on their gender-specific approach to organizing and empowering low-income women.

The task was daunting: The traditional family planning approach had been least successful precisely where the need was greatest, that is, in the remote rural areas where Peru's poorest inhabitants reside. Almost two-thirds of Peru's rural population is defined as living below the poverty line (61 percent), in contrast to the national average of 37 percent, and educational attainment in rural areas is only a fraction of what it is in more developed urban areas. Ninety percent of rural Peruvian women live in communities with low availability of public services, compared to 17 percent of their urban sisters. Maternal mortality rates in Peru, although listed in the medium range of developingcountry standards, are elevated (265 per 100,000 live births), and are thought to be twice as high in rural as in urban areas (Moyano et al. 1997, p. 131). Not surprisingly, the urban/rural differentials in contraceptive use remain significant (70 percent versus 51 percent) (Moyano et al. 1997, p. 66).

While the experiences of poor women throughout Peru are similar in terms of inequality of male/female relations and family instability (both urban and rural women increasingly report domestic violence, and the rate of female headship in Peru is about 25 percent), by definition the rural poor are more isolated than their urban counterparts. Few women in rural areas have independent incomes or bank accounts, and physical and social spaces where they can meet and interact with other women are, if not absent, at best poorly developed. While rural women living in less densely populated areas are limited in their ability to communicate and connect with the outside world, in Peru the problem is further compounded by the fact that the vast majority of rural inhabitants are Quechua-speaking; the national language, Spanish, is either a second language or not spoken at all.

The experience of ReproSalud exemplifies how, by combining the resources of a major international funding organization and a local grassroots women's organization, it is possible to move away from vertical family planning programs to more organic, multifaceted approaches and record impressive gains over a range of outcomes, including contraceptive use. ReproSalud is but one chapter, however, in the fascinating history of the Manuela Ramos Movement, which we share in the following pages. 
Over a very long lunch on a sunny afternoon, I sat with Victoria Villanueva, Susana Galdos, Frescia Carrasco, and Rosa Espinoza. At 63, Victoria is the General Coordinator of Movimiento Manuela Ramos and was one of its founding members. Susana, also an original member, is the current director of the ReproSalud project. Frescia joined the Manuelas 18 years ago, when it was still a young group. Rosa has been a Manuela for 13 years. The women have shared so much of the history they describe that they easily pick up and continue each other's comments.

\section{HISTORY OF THE MANUELA RAMOS MOVEMENT}

\section{The Early Years: Challenging Assumptions About Everyday Life}

The history of Movimiento Manuela Ramos echoes the growth of feminist organizations in many countries. In the late 1970s, Peru was brimming with hopes of restoring democracy after ten years of military rule. In the exciting milieu of a new constitution, elections, and dynamic workers' movements, a group of seven women in Lima began to reconsider their assumptions about everyday life. These women, then in their twenties, thirties, and forties, began meeting each Tuesday. They spoke of their lives, their dreams, and their frustrations and found they shared many feelings.

Sensing the extent to which other women would appreciate the kind of self-awareness they were acquiring, the group developed a workshop format that would allow other women the same opportunity to reflect upon their personal lives. Reaching out to low-income mothers' clubs, they found that, despite class differences, these women shared similar concerns. Issues of selfesteem, identity, work, sexuality, and reproductive health repeatedly surfaced and were often expressed with great intensity.

By 1980, the group formed a nongovernmental organization (NGO), hoping to contribute to a nascent national women's movement and believing that low-income women could provide vital leadership. As a fitting homage to the many anonymous voices that bubbled up during those

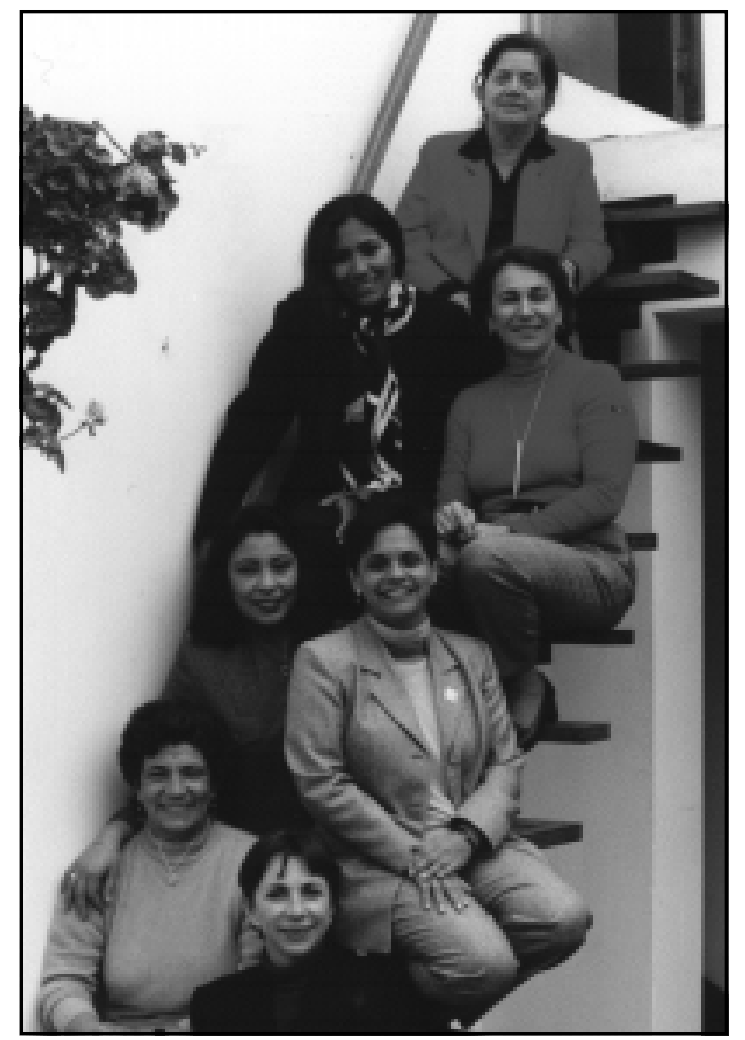

early workshops, the group chose the name Movimiento Manuela Ramos (the Manuela Ramos Movement). The name Manuela Ramos is considered so ordinary and common as to signify "Everywoman," somewhat akin to Fulana in Brazil or Jane Doe in the United States

The Manuelas' strategy was to train women community leaders in Lima's barrios (marginal urban areas). As Frescia, currently the coordinator of the Manuelas' health program, explains, "We called it training because we never found a better name, but they were really reflection workshops." What they called the "basic course" was actually quite intensive: almost 40 hours, two afternoons a week for eight weeks, with three main themes:

- Identity: sexuality, the body, and male/female relations;

- Self-worth: women's rights and history, emphasizing the "double-shift" (paid work outside the home plus unpaid labor within the home) and the fact that most women have "two bosses"; and

- Organization: teaching women skills they need to advocate for change. 
In addition, depending on the interest of the participants, themes of health and childcare were explored.

Within three years, the group had completed nine courses. Seeking greater continuity with and feedback from participants (who were also community leaders), the Manuelas began a follow-up leaders' course, training early participants to educate others and serve as resources in their own communities. Upon completion of this one-month, 60-hour course, the women continued to attend annual, and in some cases, monthly meetings; thus the Manuela Ramos Movement laid the groundwork for ongoing information exchange and organized a network among mothers' clubs and leaders of community soup kitchens.

The experience challenged the Manuelas both personally and politically. Frescia explains, "We had to find a real way to open up an honest two-way communication with women that allowed them to internalize what they were learning and express their needs. It took time." Susana agrees, "We had to learn many things step by step. We put ourselves into very real interaction with this group of women. Through this work we would keep confronting new issues and would have to reflect on how they affected us in our own lives." As an example, Victoria describes a time she was racing home after a workshop: "One of the women looked at me and asked what the hurry was. She asked, 'Can't your children help in the house? Why not stay with us another half hour?' I remember that moment."

Laughing, they recalled learning about their bodies, a consciousness-raising experience women in every corner of the world were having at the time. Victoria recalls, "Once, we realized we didn't know the size of the fallopian tube. Was it as wide as spaghetti? Too small to be seen? After the workshop, we had a huge argument about it. We argued for hours before seeking the answer!"

For several years, the Manuelas continued this work, primarily with mothers' clubs and other community groups. They rented a building in a working-class section of Lima, where the smell of cocoa wafted through the windows from the chocolate factory next door. Financial support came from several European donors, most notably ICCO (a progressive church-based organization located in Holland), which has supported them from 1981 to the present. Victoria recalls, "We were quietly working away in the Lima barrios. Friends from the political left wing told us we were wasting our time on unimportant issues like sexuality. And nobody else really knew about us."

In 1983, several of the Manuelas attended a Latin American regional feminist meeting. There they encountered other women who were involved in similar projects that were helping women to value themselves and better their lives. The experience was a watershed. As Victoria explains, "These women had a name for what we were all doing: feminism."

\section{Expanding Services}

As Peru's economic and political crisis deepened in the 1980s, the Manuela Ramos Movement soon recognized that women in Lima's slums were now coping with increasing problems of diminishing public services. "Women were also beginning to talk to us about domestic violence," Victoria says. "In those years, there was no law against domestic violence. At the same time, the law required that a woman had to secure her husband's permission to work. The Civil Code consolidated women into a completely subordinate position."

Because the Manuelas had already committed themselves to the cause of women's empowerment, the next steps seemed obvious. Between 1983 and 1986, they deepened their work in several marginal neighborhoods. First, they sought to teach women nontraditional jobs such as carpentry, but, recalls Frescia:

The women wanted nothing of it! They wanted to learn sewing and cosmetology, to be better mothers and wives. We didn't see how to work it all out, challenging the traditional female role and reinforcing it at the same time. When we went to the community of Pamplona Alta, the women talked about their health needs. We decided this was a better fit for us.

Reflecting further, Frescia clarifies how the health program took form: "Really, we had begun with sexuality. I don't think we even had heard the term reproductive health back then. But we saw the need for more comprehensive services, more respectful care, and far better in- 
formation. That's how we started in Pamplona Alta."

Pamplona Alta began as a series of invasiones. An invasion is a squatter settlement that springs up almost overnight on a previously abandoned dusty hillside outside Lima. Almost en masse, squatters appear, each claiming a tiny space where they erect a makeshift home, often made out of cardboard. Over time, the lucky or resourceful manage to rebuild with more durable materials and the residents organize the networks and services that give life to a neighborhood.

In Pamplona Alta, the Manuelas created a women's health clinic, a legal services program, and, finally, a small income-generating project. Somehow the project managed to combine sewing and politics: The women of Pamplona Alta sewed arpilleras, traditional decorative textile collages, which in this case illustrated their lives and dreams. Friends and visitors passing through the Manuelas' headquarters could buy arpilleras depicting domestic violence or women's health services as well as those depicting colorful gardens and market days.

To operate the health clinic, the Manuelas trained 23 local women to be neighborhood outreach workers, receptionists, and even clinicians. Aware that most women in Peru had more children than they wanted, they offered a wide range of contraceptive methods-probably the widest range available in the country. They provided barrier methods (including diaphragms when they could get them-usually through feminists in Brazil), ${ }^{2}$ pills, intrauterine devices (IUDs), DepoProvera ${ }^{\mathrm{TM}}$, and full instruction on fertility awareness (rhythm methods remain the most widely used method in the country). They also provided referrals for sterilization and, later, for Norplant ${ }^{\circledR}$.

In addition to contraception, the clinic also provided comprehensive reproductive health care, including prenatal care and screening for cancer and sexually transmitted infections (STIs), although, at the time, Pap smears and STI testing were almost unheard of as part of routine care for poor women. Clearly ahead of their time, the Manuelas believed that counseling and personal respect were central to providing quality reproductive health care and that sexuality was intricately related to almost all aspects of such care. Hence, staff training included

\footnotetext{
2 See Díaz, Margarita and Debbie Rogow. 1995. “The Coletivo: A Feminist Sexuality and Health Collective in Brazil," Quality/Calidad/Qualité, no. 6. New York: Population Council.
}

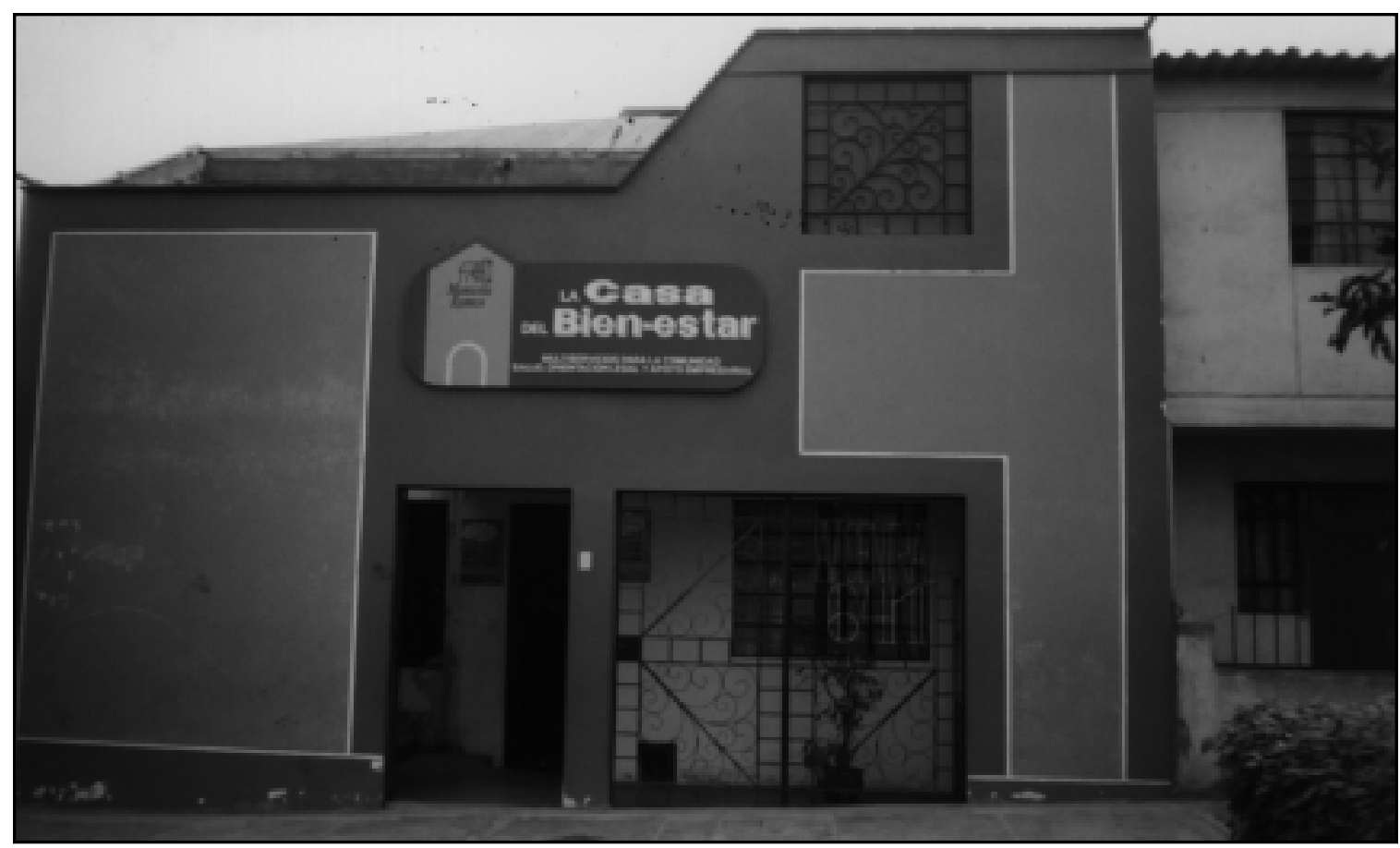


basic information and skills for sexuality education and counseling, including listening skills, aspects of human sexuality, gender dynamics and the right to say no, sexual pleasure, masturbation, and cultural aspects of human sexuality.

Dominga Florian Pachas and Cristina Yachachon Verasteguo were among the original residents hired in 1989 to staff the Pamplona Alta clinic. Today they still welcome neighbors into the clinic, now housed in a terra cotta-colored building erected by the Manuelas last year. Dominga describes how she came to work with the Manuelas:

I am 53 years old, so I was 44 then. Of my seven living children, I still had five at home. I was the head of the Vaso de Leche [ a community food program, literally "Glass of Milk"] here in Pamplona Alta. The Manuelas advertised for health promoters and I was one of the women picked. We went through a six-month training. It was not at all what I expected! I thought it would be a narrow health topic, but it covered so much. What I remember most, even today, was the part on self-esteem. This point was new for all of us, but so important. Also the unit on helping the community; we have so many problems here, with illness and with social conditions.

I have learned so much here. Now I prescribe drugs and do breast exams, Pap smears, and pelvic exams. We always offer the woman a mirror so she can see what her cervix looks like. I don't do the wet smears to test for infections, but a few of the other promoters do. I can also remove IUDs, treat cuts, and provide education about family planning. We provide pills, DepoProvera, foaming tablets, condoms, and IUDs. We explain rhythm and fertility awareness. And we make referrals for Norplant, tubal ligation, and vasectomy.

In 1989, I went to Peru as part of an international evaluation of family planning counseling services, where we visited the most prestigious family planning service sites in the country and observed client-provider interactions. Later, we paid an informal visit to the Manuela Ramos clinic in dusty Pamplona Alta. My colleague sat stunned, watching Dominga and her colleagues at work. My colleague described the services we saw there as "the best thing going on in the country, and nobody knows about it." But the local women appreciated it. Dominga recalled one woman who complained of discharge and abdominal pain:

Upon examination, her cervix was found to be inflamed. The physician gave her a prescription for treatment and told her to abstain from intercourse for several weeks. Five days later, she came back and asked to talk to me. She was worried because her husband was insisting on sexual relations. He was claiming that she looked fine and he didn't see any wound. I told her to bring in her husband, and two days later we did a follow-up visit with him present. Again, he claimed she had no wound. With her eager consent, I offered to show it to him. (She had seen her own inflamed cervix earlier.) We did an exam. Looking at the cervix, he asked, "What's this hole?" He couldn't believe that is where the baby came through.

I even told him I had once had such an infection before. For a while, he just couldn't take his eyes off that cervix. Then he said, "Take out that iron thing [the speculum], so my wife can be more comfortable. Now I understand." He told her to rest. We congratulated him for having accompanied her. She got better. They are still very friendly when I see them in the market.

Her colleague Cristina agrees that education and counseling are critical:

The men are so machista. They think women are the source of all the infections. So I show them the plastic penis I have. I ask them what they know about a particular infection. They tell me that they shower daily to avoid infection themselves. But I explain it to them. I even teach them to pull back the foreskin and wash!

Other cases are more painful. Cristina speaks of a local paraplegic washerwoman:

Last month, she was coming back from delivering clothes at 7:00 p.m. when a young man raped her. Robbed her, too. He left her in a ditch and she had no way to get out until someone came along. This week she came here crying. It is always hard to understand her speech, but I really tried. She was so worried, because her period had not come. We did a pregnancy test and it was positive. She cried. She had contracted an infection, too. She came back in this 


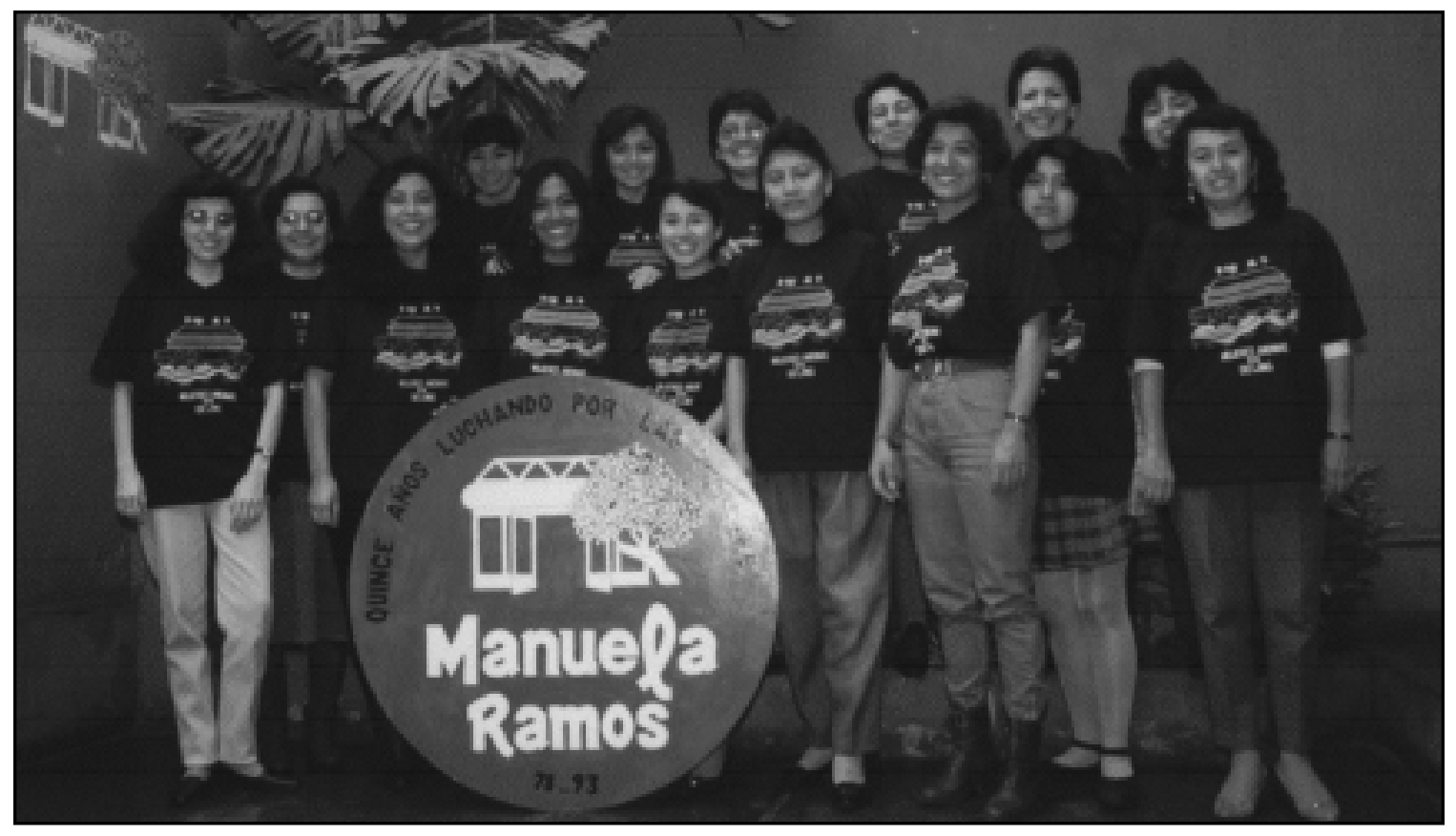

morning, but I wasn't here. She will be back later today. We still don't know what will happen.

By the end of the 1980s, the movement was growing more visible, both through its services and by participating in public protests. Still, the Manuelas were often ridiculed or marginalized by critics. Victoria reflects back on that time:

We talked about gender relations and that made men nervous. And at that time most people had a naive and caricatured view of feminism. They characterized us as divorced women, hating men, not caring about the family. The funny thing was that we were almost all married women raising our own small children!

\section{The Policy Stage}

As happens with many dynamic NGOs, the Manuela Ramos Movement began to evolve as it recognized that its ability to effect change by providing services was constrained by the social structure and laws in Peru. The legal program, which had been providing assistance to women suffering domestic violence, now began organizing protest marches. I observed one such march in the slum of Villa El Salvador in the early 1990s. Close to 1,000 women - a solid majority of the female residents not at work-marched. Bands played! Stilt-walkers were transformed into 30foot-high marionettes! Virtually the entire town- ship was either in the march or watching it. Surely, there wasn't a household in Villa El Salvador that lacked for conversation that evening. Subsequently, the legal program began working with judges and the police and helped promote legislation to expand women's legal protection and recourse against physical and sexual abuse.

Soon the health program was moving along a similar trajectory. Susi Chavez, the midwife who ran the Manuelas' clinics both in Pamplona Alta and at their urban headquarters, recalls this stage vividly. One day, a new invasion had appeared in the Pamplona Alta area. Word came to Susi that one of the squatters, a woman, was feverish and bleeding vaginally. Apparently, the woman had just had an illegal abortion but refused to give up the little plot upon which she was squatting for fear of losing it. Eventually, with Susi's support, the woman got antibiotics and was able to seek further medical help.

As the Manuelas met woman after woman seeking abortions, they became leading advocates for increased awareness of abortion as a public health problem in Peru. Abortion is illegal in Peru in all instances, except when the mother's life is proven to be in danger. Police have sometimes been posted at emergency wards to ensure that physicians report all women with suspicious miscarriages. Because the Manuelas had always worked openly and within 


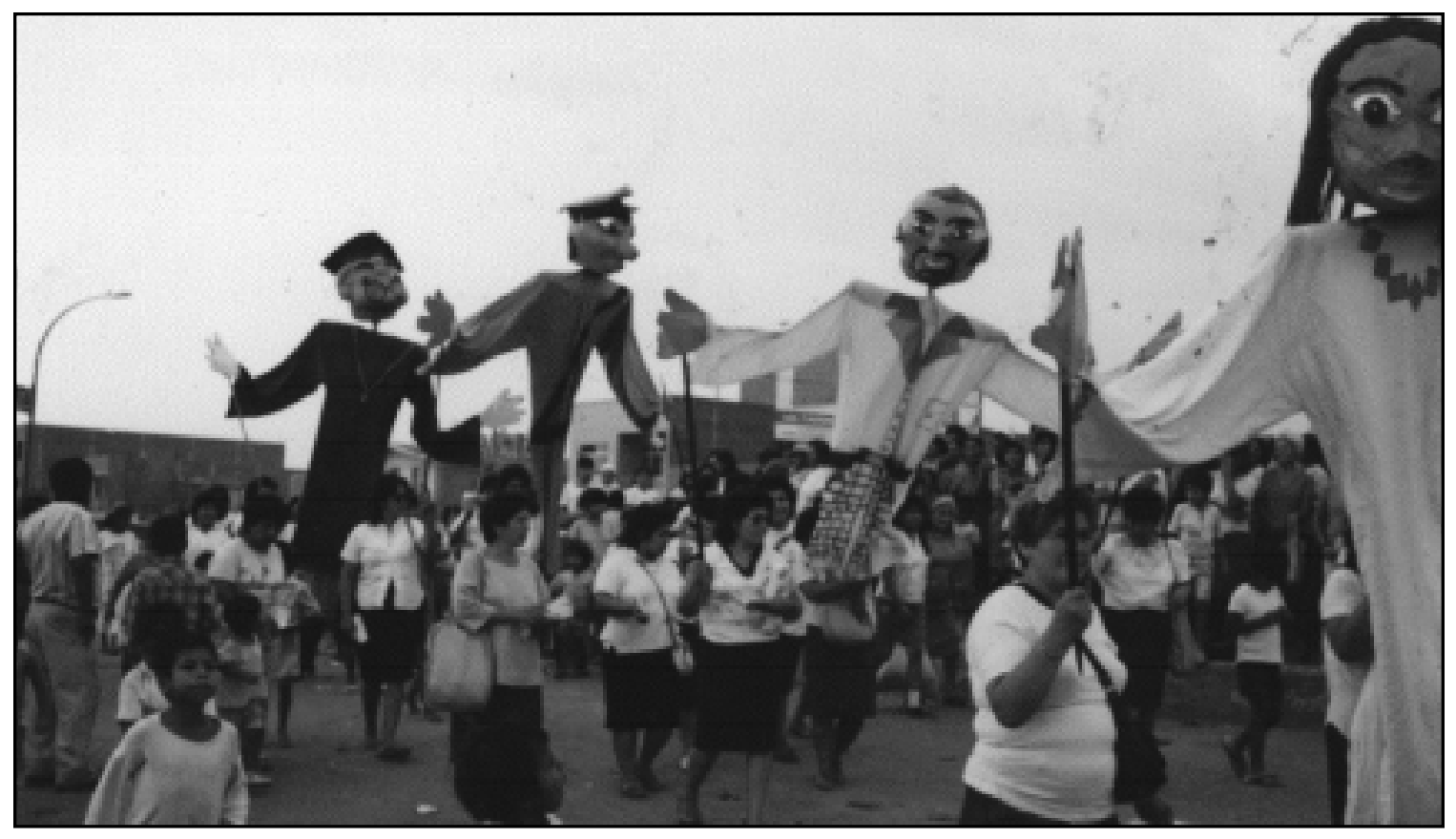

the law, and did not want to jeopardize their ongoing work, they decided to keep their activities within the Peruvian legal framework, drawing attention to the health consequences for women, sponsoring Maternal Mortality Day events, calling for humane treatment of women with complications from unsafe abortion, and otherwise raising consciousness about the reality of abortion in Peru.

Because they knew that the reproductive health care available to most women was generally inadequate, often more for lack of attention to women's needs than for lack of funding, the Manuela Ramos Movement declared itself a stakeholder in Peru's family planning community. Their 1998 20-year anniversary document describes that period:

At that stage (the late 1980s), we prioritized the creation and strengthening of highquality services. Hence, we formed women's consortia, networks, and collectives to enable women's organizations to influence political processes and decisions. This new challenge required that we analyze, systematize, and publish the experience we had developed in human rights, sexual and reproductive health, training, and income generation. A second priority was the development of our own channels of communication as well as building relationships with the mass media to in- fluence public opinion regarding equitable gender relations.

Suddenly, the Manuelas seemed to be everywhere: They published magazines, organized meetings, and attended congressional sessions; members appeared on radio and television. They continually promoted quality care, abortion reform, comprehensive reproductive health services, and greater awareness of and attention to sexuality and gender equity. Yet, during this period, the full-time staff of their health program numbered only five or six.

One of their first experiences in the broad policy arena came when the United States Agency for International Development (USAID) mission in Peru developed a new five-year country population strategy. The main focus was on long-term, provider-dependent methods that, at the time, consisted of the IUD and sterilization. The Manuelas were outraged and called upon both the family planning and nascent feminist communities to publicly criticize the strategy. They published a paid editorial in the newspaper and sponsored a multisectoral public forum. As it turned out, the strategy was only partially implemented before being replaced by one with broader vision.

Gradually, the Manuelas began to be invited to collaborate in local family planning ac- 
tivities, albeit sometimes only in a symbolic fashion. By 1990, with significant experience in both service delivery and reform behind them, the Manuelas entered the political arena as full stakeholders. They were backing selected political candidates, demanding position statements on women's rights from all national political candidates, and continuing to nurture a growing network of women's organizations across the country.

It was not an easy time to construct a women's movement in Peru. Between the military and the terrorist movement, there was little room for democratic activism. Shining Path, Peru's largest terrorist group, also began moving into new, unorganized slums; providing a few vital-but until then absent-services; and thus becoming the de facto local government. Shining Path found it difficult to accomplish its goals, however, when local communities were already autonomously organized-usually by groups of women leaders such as those who had been involved in the Manuelas' early workshops. Therefore Shining Path decided that periurban women's popular organizations were a hindrance and attempted to intimidate local activists. One soupkitchen leader was assassinated during this period and the Manuelas also received death threats.

\section{THE REPROSALUD PROJECT}

For a long time, women's health activists and reproductive health professionals have recognized that their efforts to provide contraception and to treat STIs are significantly hindered by women's restricted social mobility, limited negotiating power with partners and service providers, and even by their own low self-esteem. But the practicality of groups like the Manuela Ramos Movement had begun demonstrating effective ways to successfully address such sensitive issues as gender and self-esteem.

Just as the Cairo ${ }^{3}$ era approached, Susan Brems was named by USAID to head its Health, Population, and Nutrition Division in Peru. Trained in public health and social and cultural anthropology, she has devoted her career to international development.

In Peru, Susan decided to develop a reproductive health project that would go beyond the traditional contraceptive distribution approach, focusing instead on reproductive health and women's empowerment. With assistance from

\footnotetext{
${ }^{3}$ The International Conference on Population and Development (ICPD) was held in Cairo, Egypt, in 1994.
}

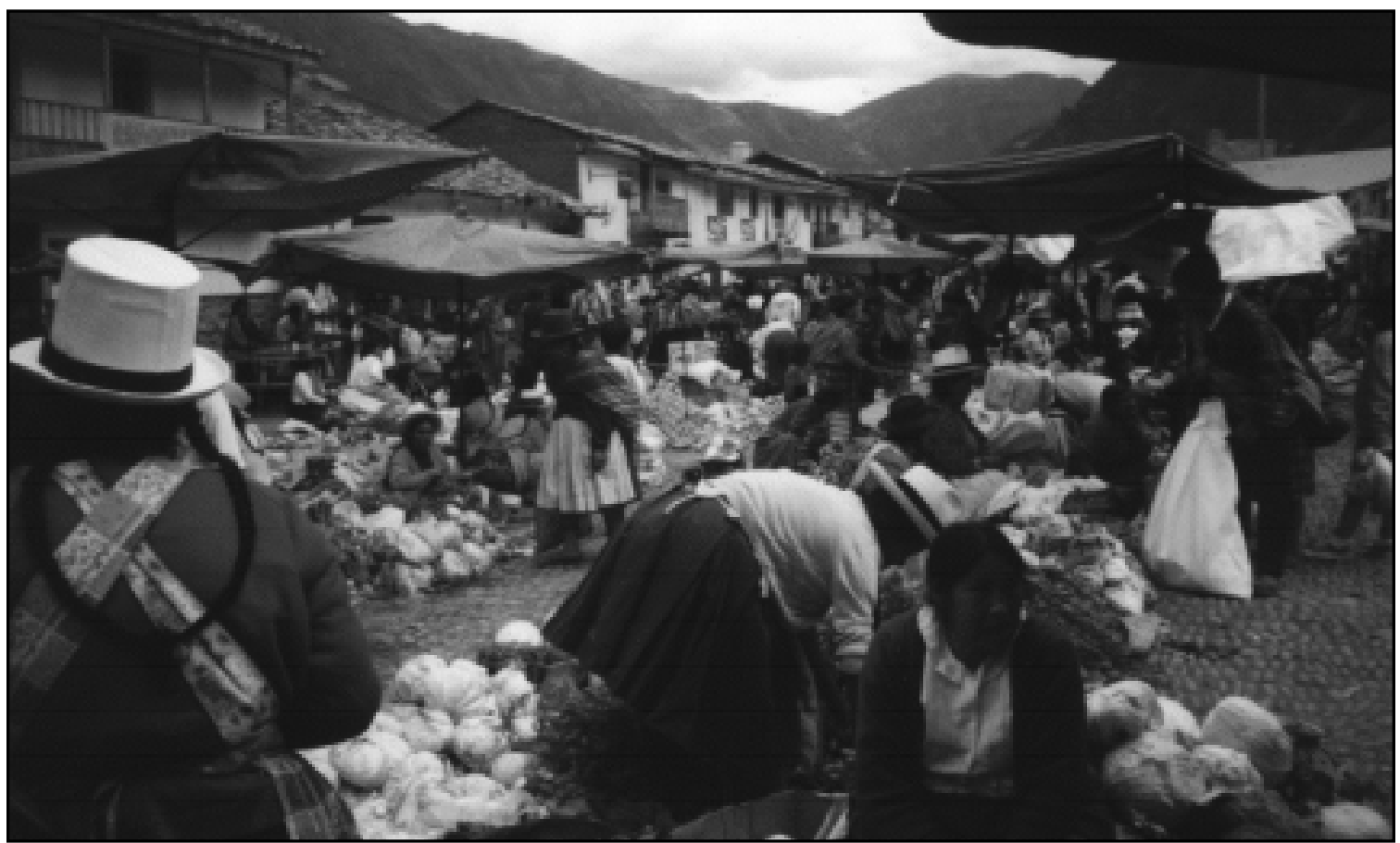


Barbara Feringa, a population fellow providing technical assistance to USAID's Office of Population, she designed a request for applications (RFA) for a project aimed to succeed where previous efforts had failed-in the poorest regions in Peru. This new, five-year project, with a $\$ 25$ million budget, would account for almost onethird of the population program portfolio of USAID's mission in Peru. The remaining funds would continue to support government and private-sector family planning efforts, with an emphasis on improving the quality of existing services.

\section{Design}

Susan is straightforward in her explanation of the origins of the ReproSalud project:

There is nothing new here in terms of reproductive health. What is new is that we are, with the mandate of Cairo, actually implementing what has been learned from the field of development. Decades of work and research in development have generated the same basic lessons: community participation and working from the ground up. These essential principles are talked about all the time, but they get short shrift in implementation. Community participation often turns into getting local folks to do the work without giving them real ownership. It's easy to have a town meeting, but building actual capacity at the local level is a different process.

[With Cairo] we have had to erase traditional assumptions about what improves people's lives. We have had to acknowledge how many of our activities are socially constructed, for example, by gender and power. We needed a different framework.

ReproSalud would invest not in traditional avenues such as a new technology or expanded service delivery but in the social and economic development of women to enable them to exert control over their own lives. Susan comments, "Problems like schistosomiasis [a disease caused by parasites] can be controlled with a single technical input. But family planning and reproductive health are one-to-one services."

ReproSalud would go into communities in areas of Peru where government and private family planning programs had largely failed to find an audience. Through individual surveys and participatory, day-long, group "self-diagnos- tic workshops" in each community, staff would gather information about women's social patterns, belief systems, and primary needs and concerns, with a focus on reproductive health. As part of this process, local women would prioritize the reproductive health issue of most concern to them. One of the mothers' clubs or food programs would then work as a subgrantee, or partner, in addressing the identified problem, with technical assistance and funding coming from the central project staff.

Three principles would be served in this process:

Knowledge is power. Local group representatives would go to a training session to learn about their bodies and about the identified health issue. These elected leaders would then go back and teach their neighbors.

Collective action is power. Project staff would work with local organizations to enable them to advocate more effectively for improved care from their local government health post, particularly with regard to the identified health problem.

Money is power. In selected areas, the project would work with local organizations to promote income-generating schemes and establish communal credit programs in cooperation with banks across the country. Unique among USAID's population projects, 16 percent of the project budget was allocated for this non-reproductive health component. Cash inputs would enable women not only to pay for the medicines they said they could not afford, but also, perhaps, to renegotiate matters of daily life with their husbands.

If all worked as planned, women's lives would change in quiet but profound ways. Their reproductive health would improve, their social mobility would increase, and their sense of selfesteem and agency in their own lives would be enhanced. The theory underlying this project was that women's reproductive health is closely linked to their social and economic situation; therefore, without engaging in a dialogue about the social context of their lives, they would have little ability to gain access to available health services. For this reason, approaches focusing solely on the supply side fall short of reaching their full potential. ReproSalud would begin by doing the longer, slower work of gender-sensitive 
development, which would enable women to promote their own reproductive choice and health both through changed personal behavior and greater capacity to shape local health services.

Duff Gillespie, director of the Health, Population, and Nutrition Division for USAID in Washington, DC, sums up his view of the agency's approach:

ReproSalud does not represent any fundamental shift in the agency's worldwide position on Cairo. It reflects a change in climate. The greater openness allows for new ways of doing things that are conducive to going outside the traditional approach to family planning and reproductive health. Officially, we encourage looking at different ways of going beyond narrow service-delivery approaches to respond to demand, to have a more holistic approach.

\section{Implementation}

Susan Brems knew she would need a unique partner to implement this project: "We wanted an organization willing and able to do work that was time-intensive, locally specific, and inductive; that is, without a blueprint. [We wanted an organization with] experience in all major aspects of the project, from health advocacy to self-help education to income genera- tion, all through the lens of gender and empowerment." This was a daunting challenge, one well suited to the Manuela Ramos Movement.

Despite criticism from some quarters of the feminist health movement (for collaborating with USAID, for risking likely failure, and for courting organizational catastrophe), the Manuelas decided to submit a proposal. They believed that, as challenging as the project would be, they could carry it out. Not surprisingly, the awarding of the project to the Manuela Ramos Movement also raised doubts, particularly among traditional family planning organizations that wondered whether a feminist organization based in the capital city could pull off this enormous and ambitious project in the Quechuaspeaking mountains and Amazonian jungles of Peru.

Having no experience dealing with the intricacies of USAID contracts, the organization spent much of the first year finding its way institutionally. Susana Galdos, who was named ReproSalud's director, gives a few examples:

We had to hire a huge number of staff. We had been such a stable staff for so many years, with such unity. Now we had to set up regional offices around the country and find people who lived in the area and spoke the local language, had the technical skills to carry out their func-

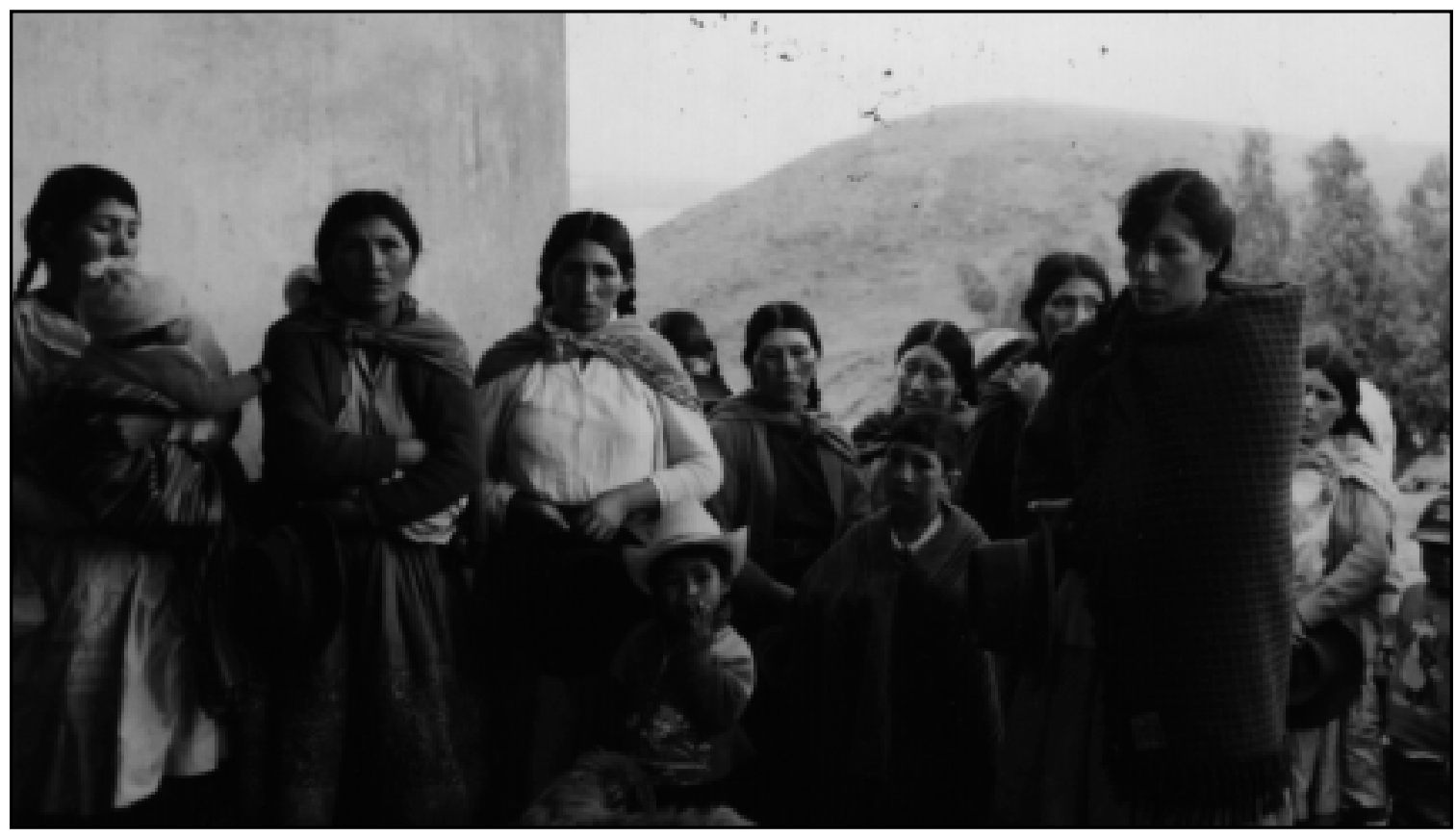




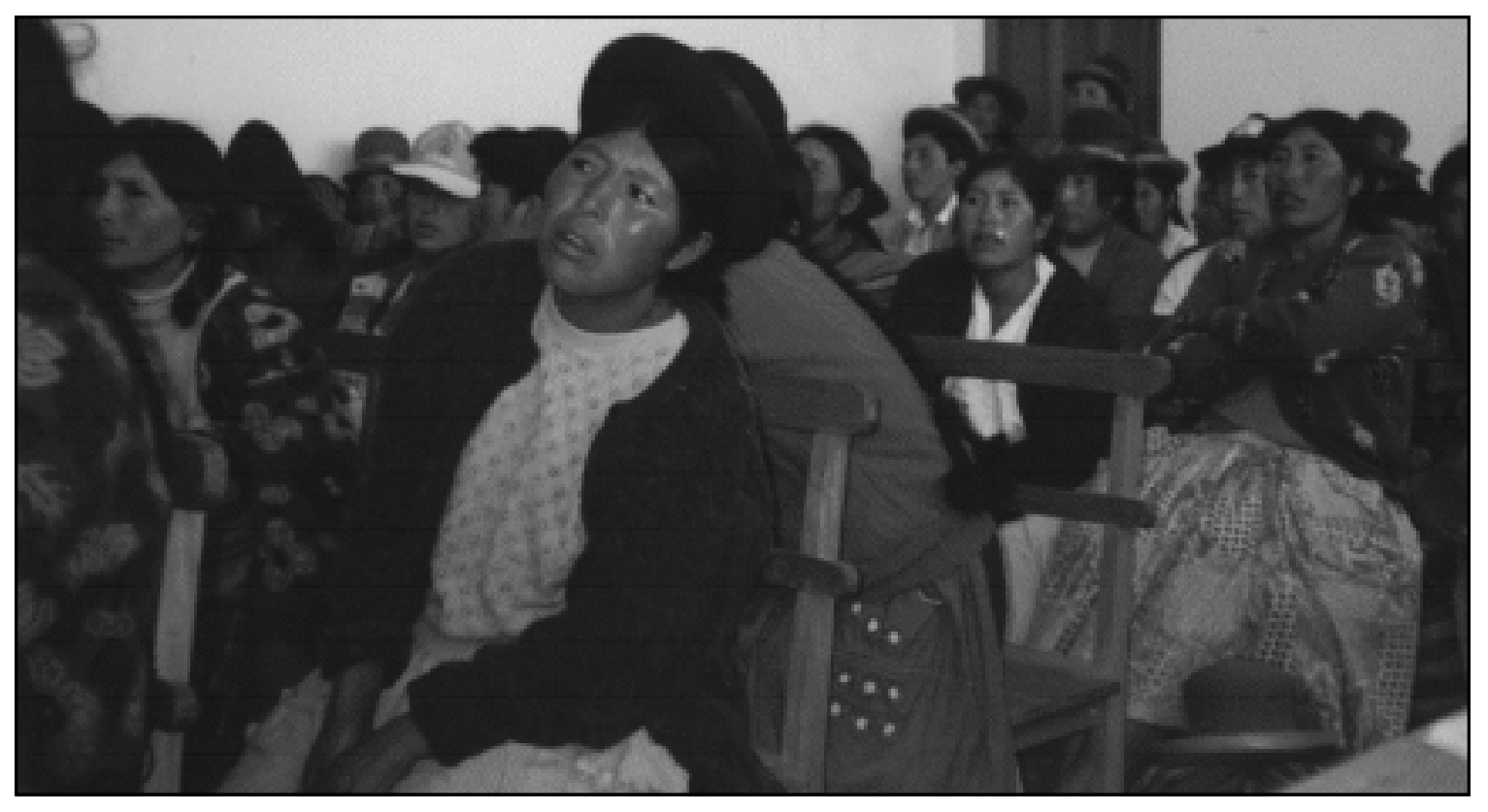

tions, and also shared our perspective on gender. This was very hard. We hired some great people but also some people who were not a good match.

Also, we had to buy a fleet of heavy vehicles, capable of going across roads that are not quite roads. Because the project is funded by the United States, we have to buy vehicles made in the United States. You won't believe the amount of paperwork and time and expense involved in getting those vehicles here. And getting parts is even harder.

The USAID mission provided ongoing support by placing senior technical advisor Barbara Feringa at ReproSalud on a part-time basis. Barbara helped the Manuelas tackle many administrative and bureaucratic challenges; without her support, it is certain that the sparkle in Susana Galdos's eyes would have dimmed long ago. For her part, Barbara says that while the Manuelas had inadequate management systems, their strong management sense brought them through the period of rapid expansion.

The Manuelas decided that the leaders of ReproSalud would have to come from the ranks of their own organization, which would greatly diminish the staff of their existing health program. In addition to Susana Galdos, Susi Chavez, Susana Moscoso, and several other Manuelas were shifted over to the ReproSalud project, leaving only Frescia Carrasco to coordinate the
Manuelas' non-USAID clinical and health advocacy activities.

A problem that has recently emerged for the Manuelas as a result of their collaboration with USAID is that the U.S. government-in response to antichoice politicians-has reinstated a policy that denies funding to any project that provides abortions, refers for abortion, or even advocates for abortion reform. Therefore, to avoid abandoning the thousands of women being empowered by the ReproSalud project, the Manuelas have had to pay an enormous ransom in terms of their right to free speech and their institutional effort to reduce a major cause of humiliation, illness, and death among the entire female population of Peru.

\section{Moving Out into the Field}

The Manuelas set up offices in nine regions that were selected for their high poverty, low contraceptive prevalence, and lack of terrorism. They hired regional coordinators, who in turn hired local promoters and administrative support staff. The promoters went out to selected villages, contacted mothers' clubs and Vaso de Leche groups, and told them an organization named Manuela Ramos wanted to help them improve their health and make their lives better.

I visited women working with ReproSalud through mothers' clubs in various parts of the country. All of them remarked on their first con- 


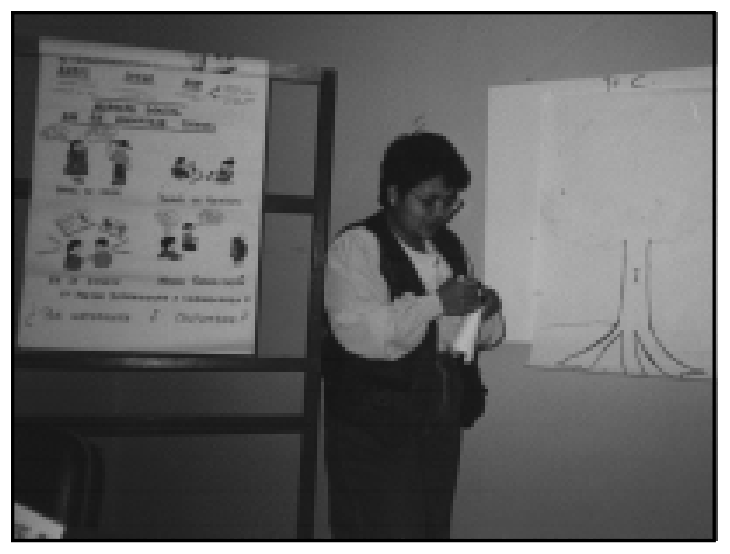

tact with the project. Women from one Quechua-speaking village told me, "Here was a group that said they were here for us. We couldn't believe it, that they didn't want anything. Usually, people come and say they are doing something for us. But then later, we are supposed to pay for it." This sentiment echoed the response the Manuelas received in Lima when they began their work there: As a mothers' club leader in Lima recalled: "My neighbor said, 'Why go? You know they don't really care about us.' But I had read about this Dr. Manuela Ramos in the newspaper and heard about her on the television. She was pretty famous and here she was, coming to our neighborhood. So I wanted to see her. I didn't know she is an organization!" And a woman in the Amazonian town of Pucallpa said simply, "They listened to me and said they wanted to support me in what I cared about. Nobody ever said that before."

The next step was to invite all the local women's groups from a cluster of towns and villages to submit a simple application giving their history and noting a specific reproductive health concern. Typically, about 15 clubs in each area responded, and regional staff then selected five finalists, inviting them to "compete" for the partnership; the competition consisted of presenting a skit about the problem they had identified.

I attended one of these sociodrama competitions in a Quechua village in the Andes. One by one, each group, consisting of about 20 women and half a dozen children (several husbands had also accompanied a group that had walked eight hours to get to the event) stood up to present its skit. Some of the skits were pre-

\section{Autodiagnósticos}

Autodiagnósticos are a participatory research process using games and group exercises designed to help women analyze their lives, identify their health needs, and reflect on how they view their health care. They are led by a ReproSalud promoter using the community's first language (Quechua or Spanish). Using the image of a tree, the group analyzes the selected problem: The tree trunk represents the problem; the branches, the consequences; the roots, the underlying causes. Carried out in three to five sessions, each lasting four hours, the autodiagnósticos are tape recorded and transcribed in such a way that the information can be analyzed and systematized as part of the project's ethnographic research component. In this sense the autodiagnóstico seeks to develop new knowledge based on women gaining a fundamental understanding of their own lives.

sented in Spanish, others in Quechua. Some dealt with the lack of adequate prenatal care, others with the need for contraception. Some were extremely well prepared and enacted, others a bit sloppy. But all were lively; soft-spoken women were transformed into drunken husbands, mothers giving birth, and nagging neighbors. After the presentations, lunch was served and participants were informed that they would be notified of the final decision by letter within a week.

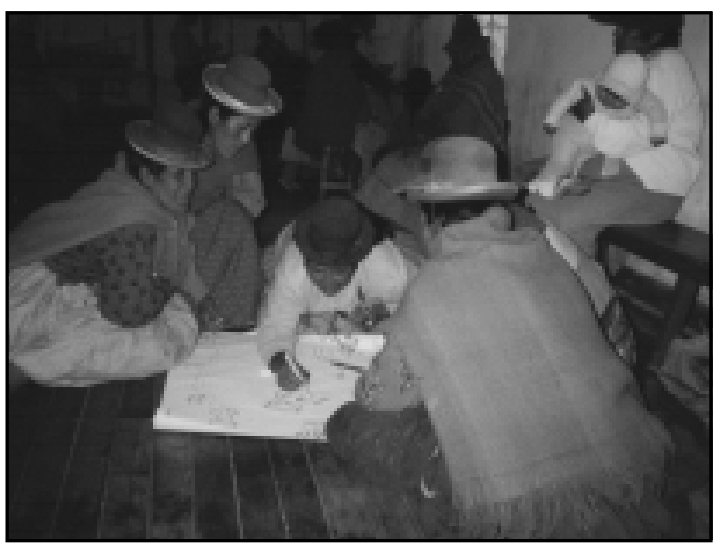


Susana Moscoso, associate director of ReproSalud, explains how the sociodramas reveal the level of social organization within a group: "Did it seem that the group had taken time to think about the issue, to rehearse, to get everyone there? Did they plan for costumes? We don't care whether they are good actors, what we are assessing is whether they are able to identify a problem and work cooperatively and effectively to try and address it. With the sociodramas, you can see this very easily."

Once the winning group was identified, ReproSalud staff collected quantitative data by surveying both men and women in the community about employment, income, reproductive health history and status, utilization of health services, contraceptive practice, and sexuality. Qualitative data were gathered through autodiagnósticos (participatory diagnostic workshops) that identified the reproductive health and gender issues local women cared about the most (see box "Autodiagnósticos").

The most common problem identified was descensos, which translates roughly as vaginal discharge. "Too many children" was a commonly cited concern in a number of villages, followed by childbirth complications, abortion, and teen- age pregnancy. Two issues that emerged as pressing concerns in virtually every workshop across the country were domestic violence and disrespectful and inadequate treatment by the local health post.

Because the Manuelas believe in listening to women and involving them creatively in their own "diagnosis," the diagnostic workshops have proven to be more than a research tool; they are also an intervention in and of themselves. Indeed, the workshops proved so revolutionary for some women that staff realized that any surveys taken after the workshop could no longer be considered baseline data because, by the time the workshops were over, ReproSalud had already started to make a difference in women's lives.

During the next stage, local ReproSalud promoters helped their local partner organizations develop a work plan. Picture a dozen women and a few babies sitting on benches and swatting flies while articulating general goals, specific measurable objectives, and concrete activities, as well as the personnel, supplies, and time frame needed for each activity. All this information went onto big sheets of paper. ReproSalud staff then calculated the budget and transferred funds to the organization.

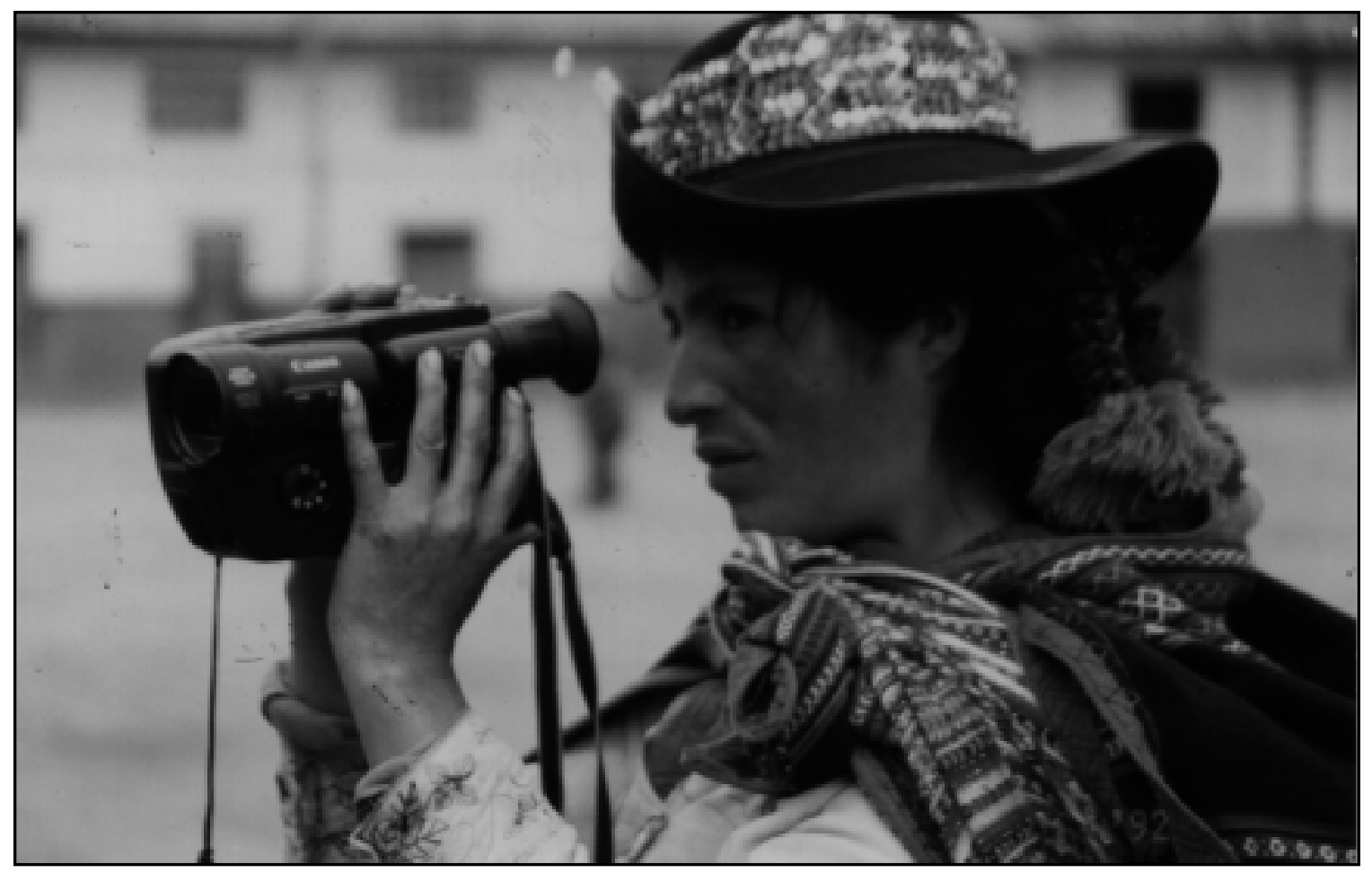




\section{Gender and Health Workshops for Men}

Most men are surprised by the workshop. They expect more technical training, but encounter instead a process of looking more critically at themselves and their culture. One of the initial exercises is called "The Male Body." It is a technique that fosters discovery of the relationship between the dominant characteristics of masculinity and the consequences or costs to the body and health. The group explores the relationship between the traditional male role and health problems, for example:

- The relationship between being "the boss, responsible, a worker (or workaholic), and strong" and loneliness, tension, stress, heart disease, gastritis, and alcohol abuse;

- The association between being a "lady's man" and having STIs and AIDS; and

- The link between being macho and defensiveness, alcohol abuse, cirrhosis, and violence.

Another exercise is called "The Tunnel of Time." By way of a directed fantasy, participants go back in time over their own history, visualizing the moments, people, and messages that had the greatest influence over who they have become. This experience is expressed artistically, with participants creating a collage with drawings, cutouts, and text. These collages are shared with the group. For most of the men, this is the first time they have systematically thought about gender dynamics in their own lives and shared experiences with other men in a noncompetitive, alcohol-free environment.

From this point of departure, the group is ready to delve more deeply into the involvement of men in violence, alcoholism, sexuality, and fatherhood. Subsequent units focus on reproductive and sexual anatomy and physiology, women's rights, gender roles, contraception, the particular reproductive health issues that the women in their community identified as their priorities in the self-diagnostic workshops (e.g., RTIs), and the role of men in familial abuse. In this last topic, which is difficult for men to contend with, the goal is to sensitize them in terms of the experiences of mistreatment or abuse that they themselves may have suffered or witnessed, and from there touch on the violence that they inflict on others. According to Benno de Keijzer:

It is key to touch their own emotionality and the cultural ideas that serve as a base for violence toward the family. In the experience of ReproSalud, we have seen the same thing that has emerged in other countries: There are growing contingents of men willing to reflect and to live in a different way.
Each women's group then elected an administrative team and a teaching team that were trained together with their counterparts from other communities. The administrative team learned basic bookkeeping, financial reporting, general management, and leadership. The teaching team learned about reproductive tract infections (RTIs), contraception, or whatever topic the group identified as its first priority, along with basic pedagogic techniques such as participatory learning. Both training programs lasted about a week. The administrative team then began to manage the project, while the newly trained teachers went back and, with assistance from ReproSalud promoters, taught their neighbors all they learned. At this point, the project was up and running.
During the first two years in the field, ReproSalud identified 79 mothers' clubs as partners and began the subgrantee process. Several clubs have now completed their first project and begun a second cycle of activities.

ReproSalud's plan was based entirely on working with women. However, early on, the women questioned this plan, because they wanted to involve their husbands in the educational workshops. In some cases, women were attempting to erode male opposition. But more often, women were going home excited about what they were learning and experiencing, and their husbands wanted to know more about the workshops.

Initially there was concern about shifting resources away from women's activities, but ReproSalud soon modified the project's design 


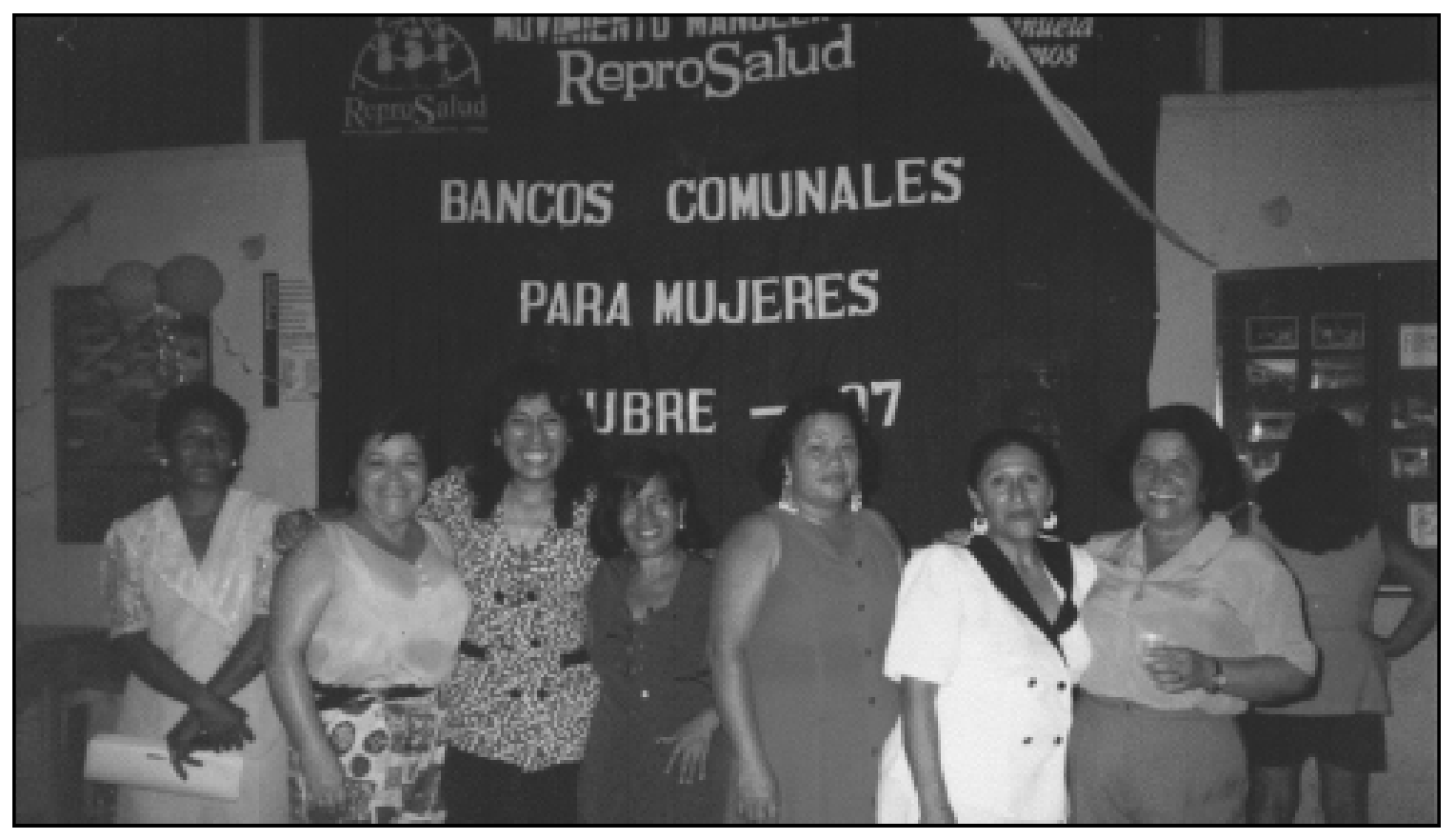

in response to the women's requests. Project staff contracted an expert in the area of men and gender-Benno de Keijzer, a male anthropologist/ physician from Mexico-to head this effort, but soon realized they would have to recruit and orient men who knew the local culture and language to serve as trainers. They also needed to develop separate materials for the men's sessions. Once a group of men from the various regions were selected, they attended a national training-oftrainers workshop. The key objective of the workshop was to create an opportunity for participants to reflect about their masculinity so that they could help other men think about sexual and reproductive health. As with the women's workshops, it was the reflective process that allowed the material to influence participants' lives. These trainers then trained male peer educators/promoters from the villages; generally, these men's wives were also involved in ReproSalud. Finally, following the ReproSalud model, local male promoters offered the workshop (with support from trainers) to the men in their communities.

The workshops were an enormous success. Men valued the opportunity to learn about their bodies and about sexuality, and they were also eager to explore ways to promote harmony in the family. This latter objective led to intense discussions about alcoholism and violence, forced sex, and communication. Ultimately, training men to work as educators of other men in their own communities would become one of the most salient facets of ReproSalud's work. (See box "Gender and Health Workshops for Men" for a description of some of the exercises in the workshop.)

\section{Income-generating Program}

The income-generating program comprises two types of activities: a village bank/credit program and product development/marketing. Originally ReproSalud planned to work with established microcredit institutions, but, ultimately, it proved more practical to work through existing banks. Currently, the program works with 20 banks in four regions. Establishing a working relationship between banks and grassroots women's organizations was quite a challenge. None of the women had ever been inside a bank before; they worried that because they were from rural areas they were not dressed properly or that not speaking Spanish would hinder them. To overcome these hurdles, ReproSalud staff accompanied them on their first visits to show them how the system worked.

Although the credit system was intended to help women establish microenterprises and meet their own health expenditures, many women have taken out loans for a wide range of needs, such as 
family transportation costs or buying medicine for sick husbands. The program works on the assumption that it is not the role of the lending institution (in this case ReproSalud) to determine the viability of a woman's request. If a woman feels that the best investment is to help her husband get well, and thus begin earning income again, that is her choice. To date the vast majority of loans have been used to support commercial activities or pay off existing loans. All loans are guaranteed by the local women's groups and the repayment rate is 97.8 percent. As of February 2000,183 banks are participating, and the microcredit program is expected to reach sustainability by the end of the year-well ahead of the accepted time frame for most microcredit programs.

\section{Market-led Product Development}

One of the larger enterprises supported through the credit program is in the Amazon town of Pucallpa. After a study of locally available resources and market export opportunities, the group decided to begin producing decorative brooms made from palm fibers and handmade paper from banana trees. Marilena Da Souza was elected project leader because, although new to the group, she had completed high school and had worked for a few months as a nurse. Marilena recounted her story:
I married at seventeen, just after I had started working. My husband didn't want me to work, so I kept house and had four sons. Staying home alone, I got lonely and discouraged. Last year, I started coming to the mothers' club, even though my husband didn't want me to. On my first visit, they made me secretary! Being with the other women, you don't feel as lonely; you get motivated, you can get more confidence. Then the people from ReproSalud came to talk to us about the project. The group named me coordinator. It's a lot of responsibility. The women had to learn that you have to come to work. Every day. You have to be responsible.

The group has just sold its first shipment of brooms for export. They will use the money to buy "things we can't pay for now-school fees, medical attention. We are going to have a big celebration."

Overall, ReproSalud's product development activities are beginning to bear fruit, with some projects already getting orders from international retailers. However, the investment of time and money required to build these initiatives into sustainable, profitable enterprises is enormous, particularly as microenterprise is not the area of Manuelas' greatest expertise. For these reasons, ReproSalud has decided not to expand product development activities beyond the five regions where they have already begun this work.

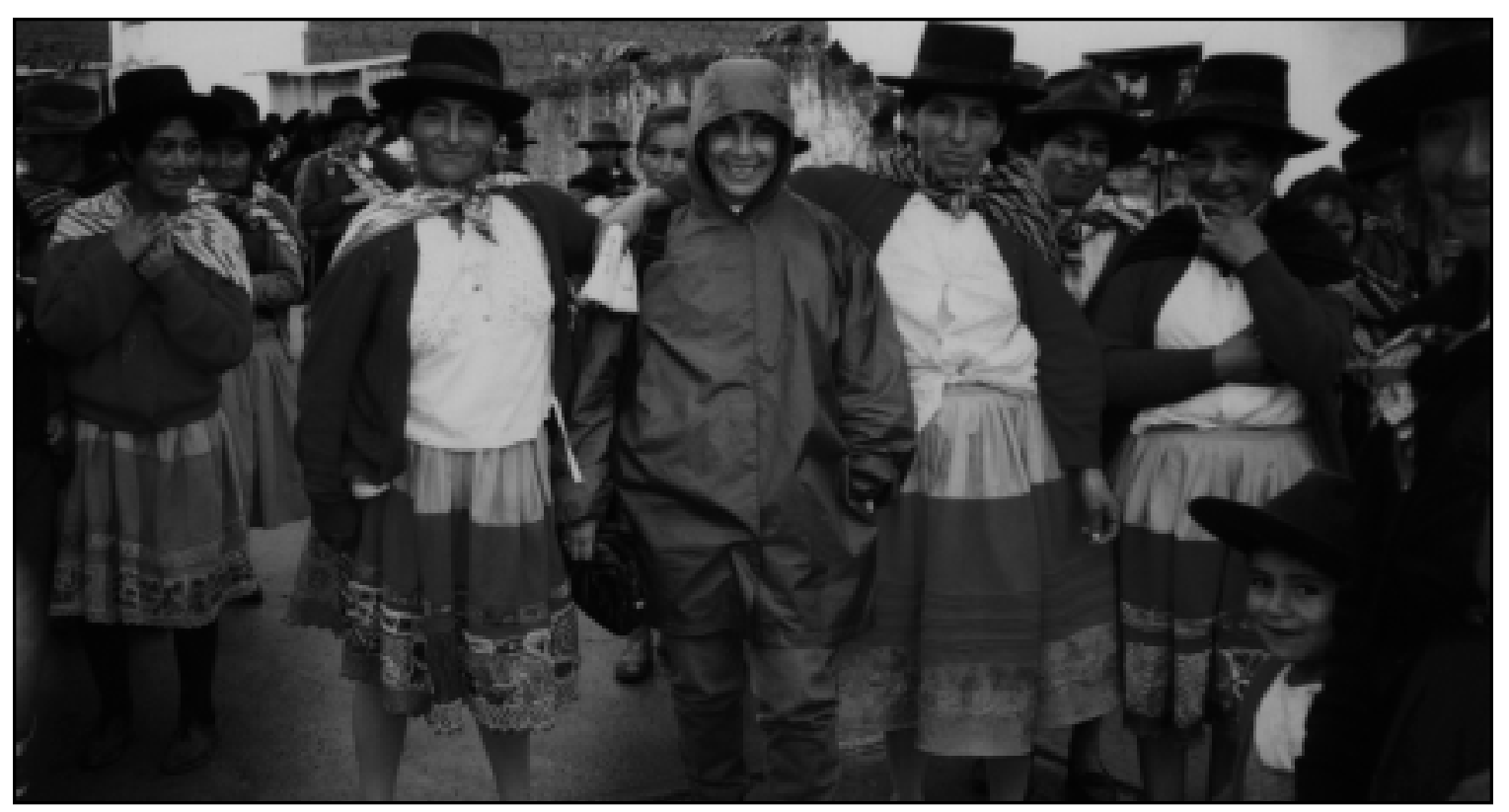




\section{Advocacy}

Because ReproSalud is a population project, one of its goals is to contribute toward greater utilization of family planning services. However, as long as women find the quality of local reproductive health services unacceptable, they will not use them. Hence, a key project component is to enable the mothers' clubs and Vaso de Leche groups to become effective advocates for improved local health care.

In the Huaraz region, where there were many complaints about local health posts, a Quechua mothers' group has been pressing for better services. A young ReproSalud promoter described the women's growing confidence:

They go right up to the [public health] authority. At first, you can see he thinks they don't know anything about family planning. They tell him about their analysis of their problems, the causes, their needs, and their plans. And then he sees how much they do know! For me, this is the best moment.

Nydia Villavicencio Rios, the ReproSalud coordinator for the Ucayali Amazon region, explains:

The women say the nurses insult them and tell them, 'This will hurt. You should have thought about it before!' They would never speak this way to a middle-class woman. So the women stay in their own homes to give birth-70 percent of the city-dwellers and 90 percent of those in the rural areas. When I first met these women they were afraid to go to the health center and speak up to the doctor. Now they go straight to the mayor! They knock on his door, step firmly, go up the stairs, and air their concerns. They inform him of their work and tell him what they need, 'A school, Mr. Mayor!' I have a proud little place in my heart when I see that.

\section{Impact}

The launching of ReproSalud raised another important question regarding how such a project could be evaluated. Despite the commonsense wisdom of ReproSalud's design, the complexities of studying its impact have been the biggest challenge. As Susan Brems explains:

At USAID, we manage for results, and this is a two-edged sword. On the one hand, we are spending taxpayers' money and we have to show something for this. On the other hand, the process of development is as important as the product. When we take shortcuts, as has happened with many projects - including USAID-funded ones-there is no long-term sustainability. The process that leads to sustainable development is a slow one. We have to temper one approach with the other.

Questions of both philosophy and methodology loom large. What is a realistic time frame in which to anticipate an increase in contraceptive use? Who may properly be considered a beneficiary? If no increase in contraceptive use is found, will improvements in women's overall reproductive health and status justify the project? What are the best indicators of women's empowerment? What is the appropriate mix of qualitative and quantitative research for assessing the impact of such a project?

Liz Maguire, former director of USAID's Office of Population in Washington, was aware of the pioneering role the Manuelas needed to undertake in developing effective evaluation measures: "This is a different program. We need quantitative aspects of the evaluation, but also qualitative ones. We must document the process, letting the women speak and letting us hear them. The concern for us is how we can learn from this wonderful opportunity."

Duff Gillespie remains more focused on the quantitative outcomes:

There's a tendency for different international groups to identify "worthy" outcomes as markers of a successful project, without showing a link to the underlying mission, which for population is still, basically, changes in fertility behavior.

Yet while the number of direct beneficiaries of this $\$ 25$ million project may be limited, the long-term benefits of large-scale, top-down projects are also questionable. As Judith Bruce discusses in the introduction to this issue, traditional family planning models have often led to failure and wasted resources. Even when they reap some success, says Susan Brems, "top-down projects eat a lot of money on travel, cars, and top-level salaries."

Certainly a project such as ReproSalud is more difficult to evaluate than one that counts 
bodies or the number of contraceptives that have moved through a warehouse. Susan points out, "Measures such as CYP [couple years of protection] are used precisely because it is hard to measure things that indicate deep, sustainable change." It is clear that, while as a scholar and donor she cares deeply about assessing the impact of ReproSalud, she does not think that the challenges posed by evaluation should undermine a commitment to doing the right kind of work.

\section{THE FIRST RESULTS}

When the Maneulas decided to request an extension of the project for an additional five years, the demand for some preliminary documentation was increased and they embarked on ReproSalud's first field-level or impact evaluation activity: case studies in three Andean regions where ReproSalud had been working for at least one year. This qualitative effort was complemented by quantitative studies of knowledge before and after participation in the community-level workshops, as well as service utilization statistics over time, based on the logs at the health posts serving these villages. All of the findings — summarized below-were striking, given the short period of time the ReproSalud project has been active.

\section{Qualitative Impact Studies}

Using a semistructured interview guide, researchers interviewed women, men, youth, village leaders, health officials, and municipal authorities about the progress and preliminary impact of the project in promoting: (1) women's empowerment and (2) contraceptive use. To measure women's empowerment, researchers identified indicators at levels of the individual, family, and community (ReproSalud 1998). Because this project seeks to empower women to promote their own reproductive health, healthpromoting behavior was included as an additional indicator of empowerment. Data collected on family planning outcomes included changes in contraceptive knowledge, attitudes, and use.

\section{Empowerment Outcomes}

Individual-level empowerment. The indicators of women's empowerment at the individual level included:

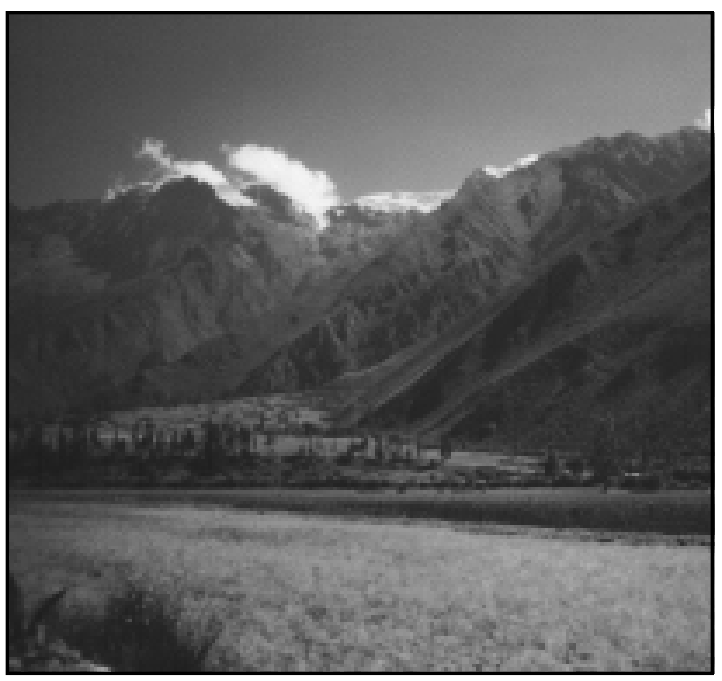

- Increase in self-esteem;

- Female control of cash;

- Knowledge of rights; and

- Knowledge of and comfort with one's body and reproductive system.

Aside from their association with general wellbeing, these indicators are also generally linked to positive reproductive health outcomes and family planning use. The following are excerpts from women's testimonies:

Once a month we come by foot and bus to the town of Huaraz to take some of our money from the bank. ... The first time we went in, we were frightened. We are not dressed like the people in the bank. We speak Quechua. And we were not used to working with cash. (Pause) But we're not nervous anymore. (A big smile lights up her face) Now we like it.

Aurelia, project coordinator in Canchabamba

I tell you, my pride follows me home.

Marilena, young coordinator at the Pucallpa broom factory

Before, we were like burros, not knowing anything. Now I feel useful for what I know, that I can know something too. Before, we knew nothing, we were forgetful, we were crying, crying. Now, we know the parts of the body and how they function, contraceptive method, how a baby is produced, how to care and eat to have a healthy baby. How to teach other women and to determine if a woman needs to go to the health 


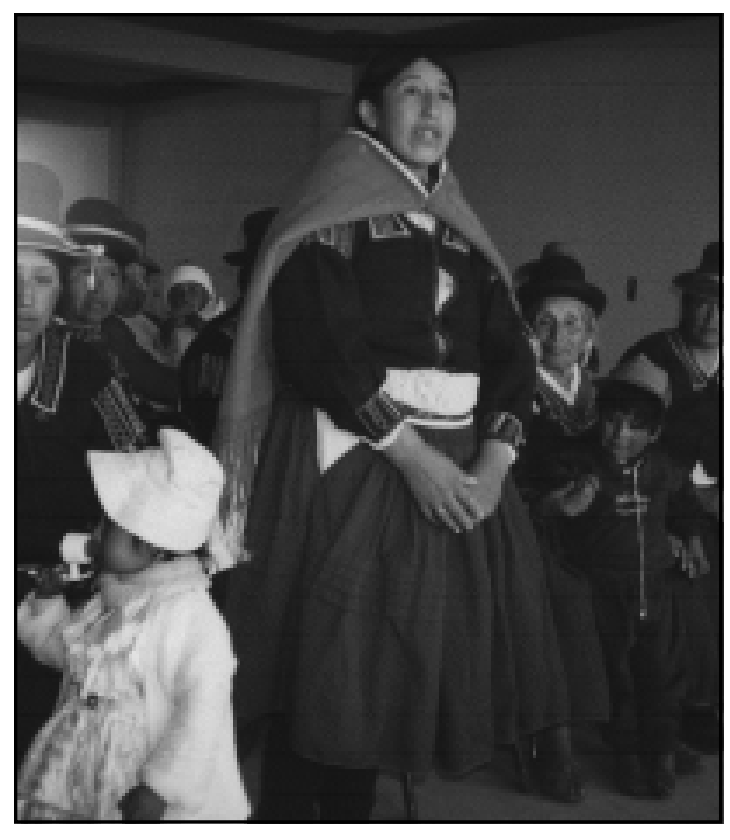

center. The rights of a woman, that nobody can mistreat us, not even our husbands, to learn to respect ourselves.

Paula, age 43 , seven children, promoter in Huaripampa Bajo

I didn't know the rights: That our husbands not hit us, not force us to have sex. To decide the number of children. To know the parts of our bodies, inside and outside. To use the [contraceptive] method we want.

Cirila, age 53, 12 children born, president of Organización de Comunidad Basada (OCB ${ }^{4}$ in Chuyo

If there is a single observation one can immediately make upon speaking with the women who are working with ReproSalud through their clubs, it is their expanded sense of negotiating skills and their heightened self-esteem.

Empowerment in the family. Empowerment at the level of the family was assessed by changes in the realms of:

- Domestic violence;

- Satisfaction regarding sexuality;

\footnotetext{
4 "OCB" refers to community-based organizations generally. ReproSalud considers all mothers' clubs and Vaso de Leche groups OCBs once they have become involved with ReproSalud.
}

- Overall family life, including more open and equal decisionmaking and communication; and

- Social and geographic mobility among females.

Domestic violence. In what is perhaps the most impressive finding of the entire study, ReproSalud's intervention, which began approximately one year ago, has apparently resulted in dramatic decreases in alcohol consumption, domestic violence, and forced sex in all of the villages we visited. While a small minority of respondents (whose husbands had not attended the men's training) reported no change in violent behavior, the vast majority of respondents (both female and male) spoke openly and at great length about this change.

Thirty men were trained. About 100 more are in the community. The husbands who have been trained understand better. Before, they brutally forced sex. They hit, especially when they were drunk. Now, no more. I see this change in my cousins. They tell me, "Thank God this help came, so my husband understands and we have left that life aside and he knows how to ask." I am so proud.

Eusebia, age 32 , subproject treasurer in Acopalca

Before, when our husbands hit us, we sat quietly and cried. Now we are not afraid. We can file a complaint; some women are doing that. Before, no. We were just cooking and crying. My husband was very difficult before. Now he went to the men's training. And he is more affectionate.

Rosa Maria, age 35, seven children, attended workshop in Huarimayo

At first I had to think about it. I had to talk about it with the other men in the training. More or less, we decided together. Those of us who changed are more respected by the women. I don't miss alcohol. My feet hurt when I drink; now I work better, too.

Alberto, age 55, 11 children, municipal official in Huaripampa Bajo

I think it's true that the men are drinking less and mistreating the women less because now they understand. Even in my own family and my relatives' families. I saw it a lot. And now I don't see it anymore. This makes me feel happy. 
When I was younger, I saw my father hurt my mother and I was very anxious. I was always very frightened when my father drank. I would like to teach young people about abuse, so there won't be any anymore.

Crispin, age 20, youth promoter in Canchabamba

Sexuality and family life. Knowledge, attitudes, and experiences related to sexuality and family life are also changing.

The training opened the subject of how to have relations, to have ... pleasure. He learned about the clitoris (smiling). It is a big change.

Juana, age 49, coordinator in Acopalca

Marilena, coordinator of the broom factory, describes how her husband felt threatened by her working:

He said, "You have more education than I do. Now you're going to earn more money than I do. You are wearing the pants in the family." But now he's running for mayor of the district and I am helping him in his campaign. My sons have learned to do more. They help cook and clean. And now my husband wants to learn how to make the brooms, too!

Ucayali regional coordinator Nydia Villavicencio Rios describes how contact with the ReproSalud project affects gender relations in the women's marriages: "The women say, 'Before, when my husband came home drunk I had to serve him [sexually]. Now I know he can't take me by force, because I have the right.' And when we talk with the men, we are finding an openness to change."

Community-level empowerment. The study of women's empowerment at the community level found increases in:

- Internal unity of the mothers' groups;

- Status and activity of the groups and their members throughout the village;

- Level of influence of the group in advocating in the larger municipal government; and

- Activity and effectiveness of the group in advocating for improvements in quality of care in local health services.

At the village meetings, more women give their opinion, whatever opinion. Before, the men would say, "Why do the women have to get mixed up in this?" Now the men don't say a thing about it.

Angelica, age 37, three children, past president of OCB in Huarimayo

Our community has never had a woman president. Yes, I could be president. I would improve many things here.

Domitila, age 33, four children, president of OCB in Huaripampa Bajo

ReproSalud is working in Huarimayo. The women are taking a great role. Their work is totally practical. They are tired of working and then being dominated by the men. They came here for help with building their house [headquarters] and we are helping them. The leaders are here all the time, and they are demanding! (smiling). The leaders are very good; despite all the machismo, they get things done. I have confidence in the women.

\section{Mayor Garcia, Head of Chavin Municipality}

Even within the same community, respondents' opinions differed about the degree of positive change in local health services. Many women felt that services had improved, while others did not think anything had changed. Leaders at the hospitals and health centers appear to appreciate the contribution and support ReproSalud is providing.

Before, the people at the hospital threatened us, that we should use family planning. They treated us like that, they put us down. Now it is better.

Primitiva, age 32 , three children, subproject treasurer in Huarimayo

Before, they didn't take good care of us at the hospital ... they said we were bothering them. We told the director that we had rights, that they needed to take care of us. Now they attend to us well; they take care of us quickly.

Angelica, age 37, three children, past president of OCB in Huarimayo

At first, we were afraid of addressing the director of the hospital. We were trembling. But he received us well. The director told us that he didn't want the people from the country to be treated badly. Now we are not afraid. But it hasn't changed. They haven't done anything. The receptionists treat us worse. The nurses are bad, 
too. The doctors are better, once you see the doctor. I think we will keep making an effort and that it will change. Little by little.

Eusebia, age 32, subproject treasurer in Acopalca

The women were complaining that they were not treated respectfully and that they had to wait too long . . . we are improving patient flow. Now they get a card and start moving through; before we had a longer process with their records. So the waiting time is less. We have also done some training with all levels of staff about how to treat patients. We check for improvements through a suggestion box. The forms have drawings for the illiterate women.

Lucy Ribera, nurse in charge of women's health at Huari Hospital

\section{Empowerment to promote reproductive} health. The last component of empowerment the case study assessed was women's ability to promote their own reproductive health through:

- Home-based health-promoting behaviors;

- Actual utilization of services (also assessed separately in quantitative analyses); and

- Effective interaction with individual health providers.

Positive changes were found for all three indicators.
Before, we didn't know anything about taking care of ourselves. Keeping our vaginas clean. Now we all know. We wash with clean water, we don't put anything inside, not even soap. Before, I used to put soap inside.

Eusebia, age 32, subproject treasurer in Acopalca

The doctor told me the discharge is from anxiety. I told him I went to a training and I know it's not from that! He remained silent.

Victoria, age 32, five children, Acopalca

Last week a woman came in to talk about agua blanca [white water ${ }^{5}$. She proceeded to describe her problem to me. She asked for her treatment. This surprised me! With the other women, we have to ask, to draw them out. They don't want to tell us. The women who have been trained by ReproSalud talk openly about their bodies. They are not inhibited.

Lucy Ribera, nurse in charge of women's health at Huari Hospital

\section{Contraceptive Outcomes}

The second component of the case study sought to assess changes related to contraceptive knowledge, attitudes, and use. The results indicated an undeniable sea change: the idea of family planning has gained enormous legitimacy

\footnotetext{
5 The term "white water" is used by local women to refer to vaginal discharge.
}

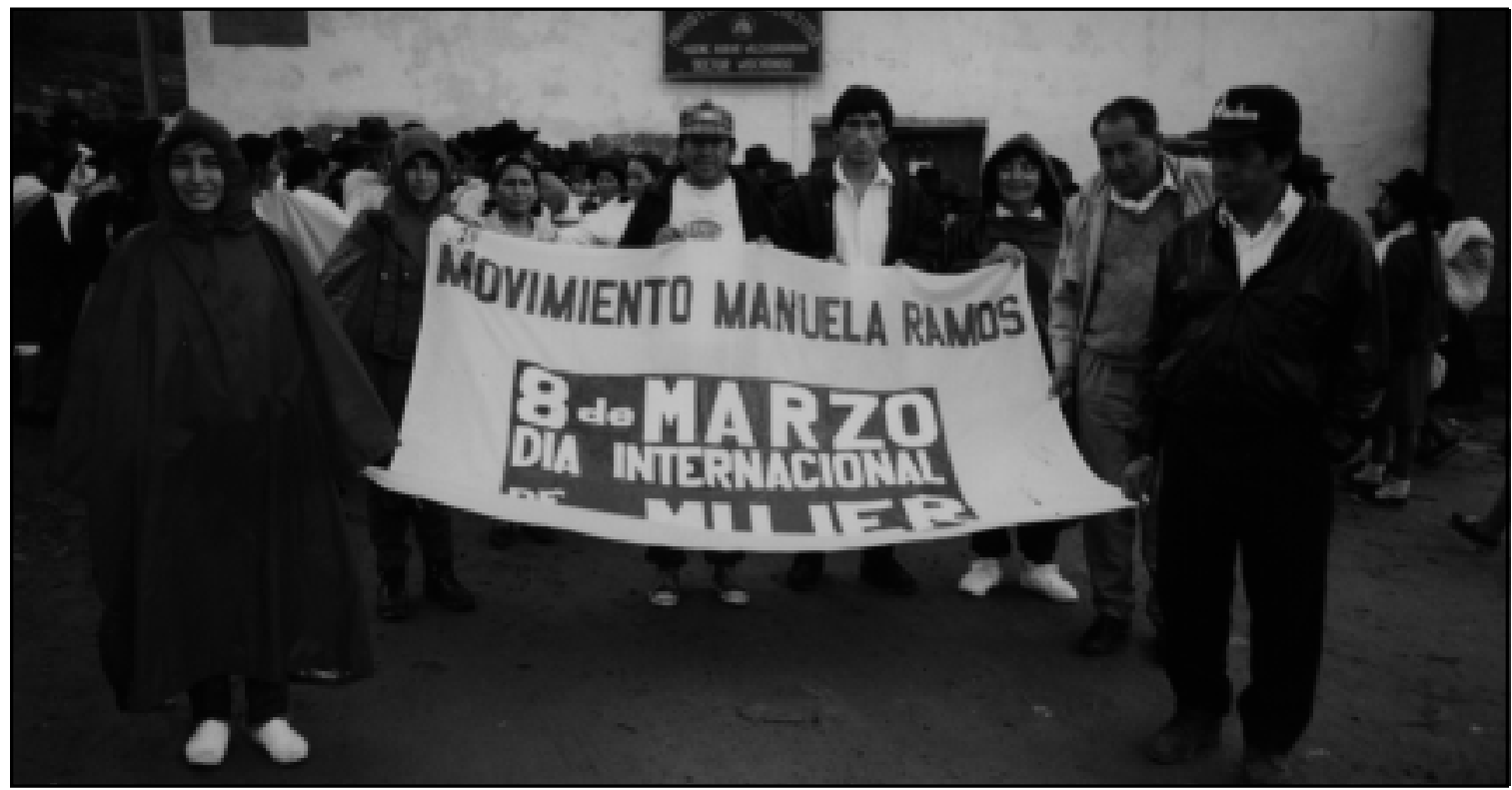


over the past year in all of the communities studied. There is a continuum from those who have initiated method use to those who are now considering the idea for the first time.

After my first child, I controlled with the period. I got pregnant, and then after the second pregnancy, I used herbs. When my period didn't come, I would take the herb and the next day, my period would come. Listening to the training about taking care, my husband decided the injection would be best. Since my last child, two months ago, we are controlling [with the injection].

Primitiva, age 32 , three children, subproject treasurer in Huarimayo

In the ReproSalud training, they talked about protecting ourselves with calendar, with pills, condom, the operation on the arm [Norplant], the Copper $T$, the operation [sterilization] for the man and for the woman. What they told me was different from what the health center people told me. . . ReproSalud speaks Quechua to us, they spend more time with us, they tell us more details.

Elda, age 34, pregnant with fifth child, attended workshop in Huaripampa Bajo

Since the talks, my wife and I take care. I prefer natural ways, according to her period, well, from time to time, the condom. Before, we knew nothing. We didn't take care at all.

Sabino, age 52, four children,

village official, attended workshop in Chuyo

The men have changed. Before, we were all like animals. Now, they have changed and I have changed. We know all about our bodies. He says there is not enough work to feed the children. Now I know what it is to control, with the injection. If not that, I will use Copper T. If that's not good, then with the pill. Any one of them.

Aurea, age 33, seven children, attended workshop in Chuyo

ReproSalud has helped these women to trust in family planning, to want to learn, to feel valued. Even if ReproSalud left the community by next year, the number of women using family planning will continue to rise. Because something has changed, and with that change, there is no going back.

Rosa Manrique, technical nurse in Canchabamba
The lessons learned from the case study closely parallel those that emerged from a multicountry evaluation, by the Global Fund for Women, of efforts to promote empowerment and family planning among women's organizations. That evaluation also found that women tended to see building self-worth and confidence as prerequisites to effecting changes in family and community life, and that participation in women's organizations promotes such individual growth. The authors of that evaluation argue that, in neglecting these personal markers, development experts fail to understand the complex processes by which women and their organizations can effect positive change.

These findings join a growing body of literature that is overthrowing the conventional wisdom that it is folly to tinker with deeply ingrained intangibles such as gender dynamics and self-worth. Heightened self-esteem and an expanded sense of what is possible are now the signature of the women - and men-whose lives have been touched by ReproSalud.

\section{QUANTITATIVE FINDINGS}

Early quantitative data were generated from pre- and posttests among a sample of participants in the community workshops. Responses showed increased knowledge of how methods work and striking increases in knowledge of the fertile phase of the menstrual cycle (from 29 percent to 50 percent); recent experience discussing family planning (from 60 percent to 98 percent); and stated intention to begin using a method within the next year (from 40 percent to 68 percent).

At the time of the case study - eight months to one year after the workshops-studies were undertaken to measure impact on service utilization. Analyses of patient logs at family planning service sites, generated by comparing the logs from a two-month period before ReproSalud began working in the area to the same two-month period a year later, corroborated the qualitative findings. While the patient logs were not of the best quality and absolute numbers remain small, dramatic increases in utilization of contraceptive services were documented among residents of the villages where ReproSalud is working. At one hospital, there was a 400 percent increase in family 
planning visits by residents of the local ReproSalud community, as compared with a 51 percent increase by residents of nearby "nonexperimental" villages and a drop in the number of visits made by residents of the urban center where the hospital is located.

The patient log at a second hospital indicated a 100 percent increase in family planning visits from the residents of the local ReproSalud community, compared with a 39 percent increase among residents of nearby villages and a 26 percent increase among local urban residents (Rogow and Diaz 1999). The Manuelas are conducting further data collection and analysis to corroborate and supplement the case study. They will also repeat the same surveys done for the baseline at the end of the project. Still, the early results clearly support the use of holistic models that seek to enable women to control their fertility in the context of their overall empowerment. If the results from this preliminary study are confirmed by assessments in other regions of Peru and over time, they will suggest important lessons for researchers about "hardto-reach" populations that have shown low demand for contraception.

\section{ANALYZING MISTAKES AND DEFINING CHALLENGES}

Although they experienced considerable success, the ReproSalud team also made plenty of mistakes in implementing the project, which they readily acknowledge. According to Susana Moscoso, "The most serious error was taking on too much at once." Susana suggests they should not have tried to establish the reproductive health and income-generating components of the project at the same time they were trying to establish themselves institutionally. She adds that they also tried to work in too many geographic regions right from the outset, especially given the difficulties in finding appropriate local staff. Susan Brems agrees, adding that working in fewer regions would have allowed the Manuelas to understand the infrastructural needs of the regional offices before they opened so many.

There were technical problems as well. As noted above, the participatory diagnostic workshops initially preceded the baseline surveys. How- ever, because the workshops themselves were an intervention of sorts, it became unclear how reliable subsequent survey data were as a preproject baseline. Eventually ReproSalud decided to carry out surveys prior to the workshops.

The idea behind the baseline surveys was to be able to repeat the survey several years later in order to identify whether any change had taken place. It was unclear, however, what sorts of changes would be realistic and measurable at the end of the project. At first contraceptive use, health-seeking behaviors, and economic data were to be the key indicators. However, the Manuelas soon realized the need to add intermediate markers measuring greater social mobility and decisionmaking.

Another problem was the length of time required for the women to move from wanting to learn about a specific problem to actually gaining the knowledge needed to address the problem. The process of teaching women to become self-confident community educators, program planners, money managers, and advocates could take as long as six or seven months. ReproSalud was not only "teaching the hungry [wo]man how to fish," but how to make a fishing pole and how to find a river!

In addition, ReproSalud staff assumed that the project would work exclusively with women. The case studies verified that including men was a powerful force for promoting change in gender dynamics; men who attended the workshops reported profound personal changes that were corroborated by interviews with their wives.

Another problem is that establishment of advocacy activities is proving to be slower and less susceptible to direct programmatic inputs than educational or employment activities. As Susana Moscoso says, "Our advocacy work is slower than the other work. After all, we are constructing democracy."

Finally, the Manuela Ramos Movement suffered from the process of establishing ReproSalud. Tripling the staff created severe institutional shock, and the enormous financial growth of only one program in the organization (which quintupled its overall budget) resulted in administrative confusion. For example, it was unclear whether or not the newly hired ReproSalud staff were members of the Manuela Ramos Movement. Over time, not only have most of the regional staff come to iden- 
tify themselves as Manuelas, but they are also not afraid to say that they are feminists.

Gradually, the Manuelas' own health, legal, and income-generating programs have begun to interact with ReproSalud. For example, the Pamplona Alta clinic has become a ReproSalud site; the legal program has set up services in a ReproSalud office in the Puno region; and the income-generating program is still exploring ways to dovetail with ReproSalud microenterprise activities.

Yet another difficulty is the isolation of the regional staff. Charged with nurturing a selfhealth movement and overseeing credit and enterprise programs, regional promotoras have only each other and their supervisor, the regional coordinator, for support. In addition, the regional coordinators meet as a group only quarterly. "At these times," explains Ucayali coordinator Nydia Villavicencio Rios, "we tend to focus on the problems, and don't stop to talk about the successes. I feel the need for my colleagues to come see what we are doing. Sometimes I feel lonely."

There has also been occasional political opposition. ReproSalud staff met some resistance in parts of the Andes where there has been acute controversy over the government's tubal ligation program; one mothers' club, not participating in the program, spread the rumor that the ReproSalud staff were part of the sterilization campaign. In other settings, leaders of the Catholic Church initially tried to dissuade the mothers' clubs from participating in the project. However, when priests and nuns found out that the women themselves chose the problems they wanted to work on, they could no longer say that the program was being imposed by outside groups. Finally, the Manuelas had to cope with envy and resentment among some agencies that had not been invited to participate and health ministry personnel who had expected more direct influence over project activities. In each case, ReproSalud staff sat down and talked openly with their critics and, over time, were able, at least partially, to win them over.

Ultimately, however, the success of ReproSalud rests largely on a factor that the project cannot control: the responsiveness of government to improve the quality of services. Advocate as they may, women will only increase their use of local public health services if those services actually improve in response to their needs. Such change is slow at best. As Nydia Villavicencio Rios explains, standing by a banana tree that will soon be stripped to produce paper, "Even with all we are achieving, this is a slow process. We are changing people. We are changing institutions." Susana Galdos expects that ReproSalud will help create communities of healthier and happier families. She anticipates inroads into problems that have seemed intractable for decades-problems such as high levels of unwanted fertility and domestic violence. Further, she knows ReproSalud will leave be-

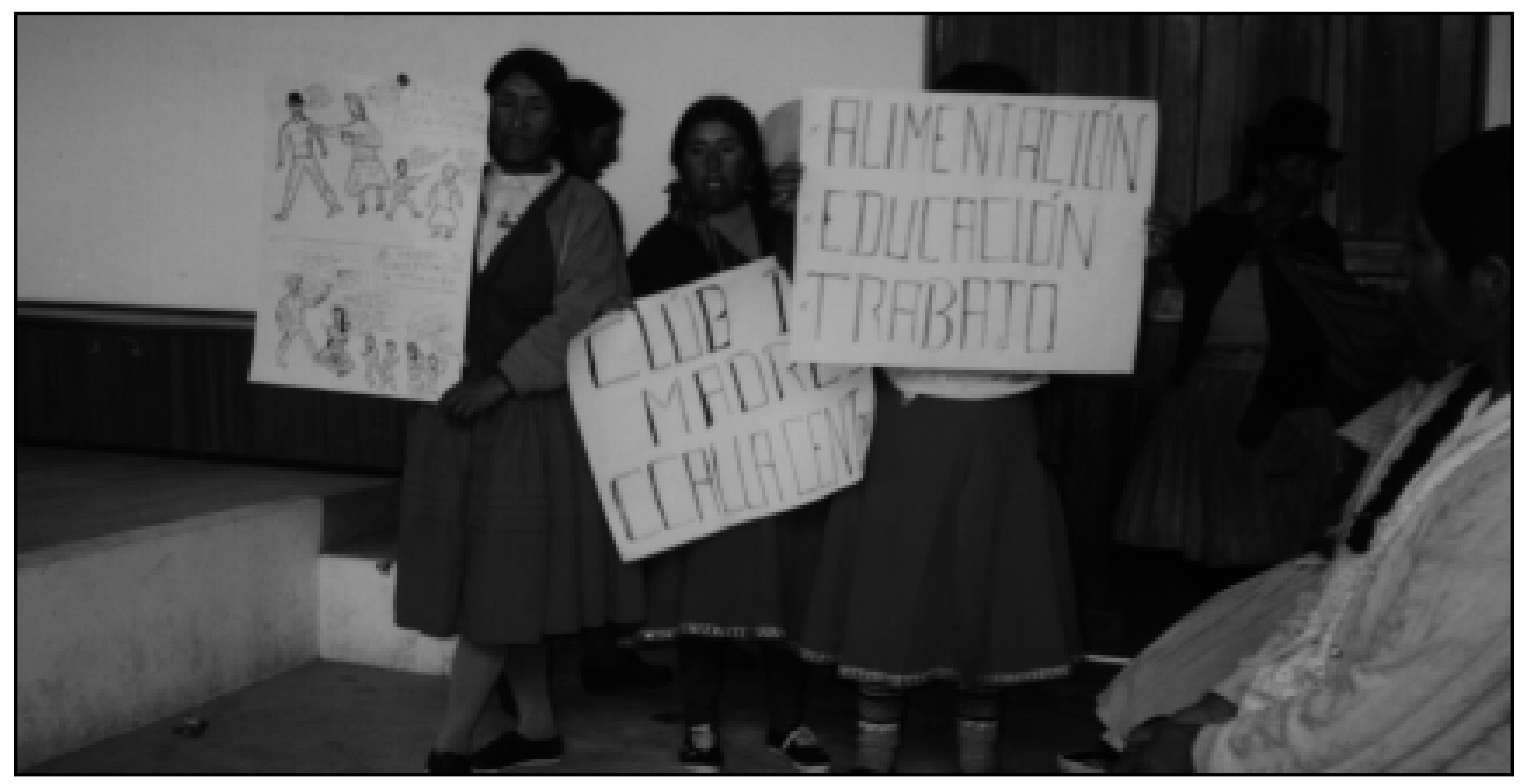


hind a group of experienced community leaders-women with skills, courage, and a track record of working for change.

Everyone seems to agree that ReproSalud has blazed new paths in just a few years and also that it will not be possible to accomplish all it has set out to do in the five years initially allotted for the project. Therefore USAID has now extended the project for another five years. Although the departure of both Susan Brems and Barbara Feringa from USAID/Peru may reduce the degree of technical support they get from USAID, the Manuelas are confident in their ability to carry on-the final story on ReproSalud is far from written.

\section{THE MANUELA RAMOS MOVEMENT TODAY}

Today the Manuela Ramos Movement has a beautiful three-floor building in Lima, painted blue, ochre, and rust and surrounded by a sunny patio. In one corner is the Manuelas' crafts store; on the patio, two women are meeting with a ceramist, explaining how the store can work with her. The Manuelas' general offices are on the second floor; the third floor is devoted to ReproSalud. While the Manuelas have hired some 100 people to work on the ReproSalud project, the original Manuelas rely on a staff of 40, three of whom were part of the original Tuesday-night group from 20 years ago. Rosa Espinoza comments, "People always wonder about the stability of the staff. But we are not working for a salary [salaries at the organization are low]; we work for an idea. We value the chance to implement our ideas through this work. And we have done it all collectively."

The original founders of the organization recall with pride their rise to prominence. Victoria Villanueva laughs, "The organizations that criticized our concern with personal life issues - well, 20 years later they're no longer around, and we continue to thrive." The Manuelas are mentioned in the press almost daily and are invited by the medical community to speak, advise, and collaborate on a range of health initiatives. They also have very high credibility in Congress, where their word on reproductive health issues carries enormous weight. During a national crisis over poor technical quality and inadequate informed-consent practices of the government's tubal ligation program, one legislator grandly called for "testimony about this crisis from Dr. Manuela Ramos." The entire Congress laughed as all but the unfortunate speaker knew that Manuela Ramos is not an individual, but an organization-and Everywoman at that. Indeed, at the organization's 20-year anniversary last year, Congress awarded the Manuela Ramos Movement a Medal of Recognition for its contribution to health.

The Manuelas' nonhealth activities also continue to grow. Aside from the roughly $\$ 4$ million annual budget for ReproSalud, the organization spends $\$ 1$ million every year to support its ongoing service and advocacy projects. As Victoria explains:

We have succeeded in helping get some progressive legislation passed. But implementation of these laws is still a problem. In some cases, people in the rural areas have not even heard of the laws. In other cases, the powers-that-be are dragging their heels. So we are devoting energy to promote and monitor enforcement of the new laws.

For example, until 1997 Peruvian law stated that a man could not be arrested for rape of a female 14 years or older if he later married the victim. In the case of gang rape, all the rapists could be let go as long as one of them married the victim. In some cases, the perpetrator was let go just for offering to marry his victim, even if she refused. Rosa explains, "Many legislators and journalists view domestic violence as normal in the indigenous communities. From our work with these women, we can assure you they do not feel this way."

Another example is Peru's new law requiring that political parties include women as 25 percent of their slate of candidates. To help implement and monitor this law, the Manuelas have formed a broad, nonpartisan coalition of women's organizations that are working to identify strong women candidates and mobilizing women to vote. The Manuelas are also concerned about developing leaders from the next generation. Susana reflects, "We haven't really had a strategy to incorporate youth. We are just now figuring out how to become a resource for young people. After all, we're getting old!" Victoria adds, "We want to see young women involved in politics."

It seems the Manuelas are not at risk of running out of work or energy. 


\section{LESSONS LEARNED}

The ReproSalud project is unique in many ways, but, in particular, it is one of the rare times when a feminist NGO has joined forces with a major international donor such as USAID to implement a large-scale program intervention. The experience of the Manuela Ramos Movement/USAID collaboration demonstrates not only that it can be done successfully, but also provides important lessons for donors, international institutions, and women's NGOs when large-scale efforts are undertaken to promote improved women's reproductive health and increase their sense of empowerment. The first three lessons are institutional; the last three are substantive.

\section{Although the Manuela Ramos Move-} ment was a small NGO, it had previous experience in almost every aspect in the project's scope of work.

2. The Manuelas were able to staff the leadership of the ReproSalud project from within their own highly stable ranks, thus ensuring cohesiveness as a team and solidarity with the rest of the organization.

3. USAID provided active technical and professional support to the Manuelassomething that was tremendously important given that the organization had no experience managing such a large and complex cooperative agreement. This allowed for a gradual process of learning administrative procedures without inhibiting the on-the-ground development of the program. Barbara Feringa emphasizes this point: "Providing institutional support to foster feminist organizations' success was a necessary part of the trust-building process" between the two organizations.

4. Clarity of purpose was essential to the success of this project. As Susana Moscoso says, "We approached this work with the right philosophy: the direct participation of women in improving their own lives." Susan Brems agrees: "Look how important RTIs are to Peruvian women. It's their number one concern in this project. Yet RTIs have not been deemed important in many public health and population circles."

5. Listening to women demands project flexibility. Women suggested parallel work with men; it was not part of the original program design. This add-on component, however, is now seen as a critical element in achieving the project's goals. The fact that the project was able to make this significant program shift is a credit to both the Manuelas and USAID and the willingness of both to be responsive to needs expressed by project participants.

6. A number of programmatic elements have proven essential to the program's success. Along with reaching out to men, building self-esteem and collective action appear to be particularly important. According to Marilena, the coordinator of the broom factory in the Amazon: "Alone you are nothing. If you think you're nobody, you are nobody. Together, we have courage, we have new ideas. Together we float." 


\section{Afterword}

With ReproSalud, the Manuela Ramos Movement is implementing perhaps the first largescale, gender-sensitive project specifically designed to grapple with the social and service-based barriers that impede the achievement of reproductive health among the most disadvantaged womenthe vast majority of whom live in rural areas. But it will take some time for the population field to learn from and refine the elements that are key to the successful development of such a program. In the late 1960s Reimert (Rei) Ravenholt, director of the USAID Office of Population at the time, outlined five steps in the development of family planning programs: (1) building facilities (the "bricksand-mortar" stage); (2) delivering contraceptives (including substantial investments in new contraceptives throughout the late 1960s into the 1970s); (3) training workers (often, but not always, singlepurpose family planning workers); (4) offering services; and (5) evaluating results. He then posited a five-year time frame before one would begin to see results from such conventionally configured family planning programs (Ravenholt and Chao 1974).

It is important that the same longer-term view be applied to ReproSalud, which has outlined steps for the development of the project but is using some very different markers and internal processes. A key difference is that the early stages of its program approach require building a social (rather than physical) infrastructure that can reach and mobilize women. A major challenge has been to find ways to give voice to women by creating safe spaces for them away from their homes where they can spend time together and, with structured support, begin to discuss and analyze their own experiences and establish their own priorities. Through this process it has been possible to consolidate a new social environment for women, and local women's organizations (some preexisting and some that are being nurtured in this new open environment) have begun to elaborate programs aimed at giving women increased economic and social authority (such as savings clubs, provision of loans, and functional education).

To work in such a new way and in places where previous efforts have failed or have not been undertaken at all requires a distinct learning phase. It is unfortunate that the "diagnostic phase," so honored in the development literature, has rarely been given its due when programs are actually implemented in the field. In the case of ReproSalud, however, the project was specifically designed to allow for this learning period to take place. As described in its USAID project document, "ReproSalud undertakes the time-intensive, locality-specific activities that are required to make reproductive health services meaningful to local, hard-to-reach women” (USAID 1995). ReproSalud's objectives and mode of operation are, therefore, seeking to address deficits-both in the servicegiving system (with regard to quality and content) and the social system - that constrain women from acting in their own best interests. It is impressive that a USAID-supported population initiative reserved 16 percent of ReproSalud's budget for non-reproductive health interventions. The availability of these monies has meant that as the diagnostic phase identified women's needs outside the health sector, there was a capacity within the project to respond.

The fledgling women's infrastructure the Manuelas have created has now begun to interact with Peru's established health system, with the result that an increasingly articulate community of women has begun to make demands on the existing health services to meet their own needs for safer pregnancy and childbearing, voluntary fertility regulation, diagnosis and treatment of RTIs, and more equitable and open communication between sexual and marital partners. And last but not least, women have demanded to be treated respectfully.

Through ReproSalud, the Manuela Ramos Movement has fostered a parallel process of interaction with rural women's male partners, based on the women's demands that their partners be involved in the project. This is of particular significance, given that male methods or methods requiring some degree of male participation (e.g., periodic abstinence, condoms, withdrawal, and vasectomies) account for more than one-third of all contraceptive use in Peru. Listening to and learning from women, ReproSalud has established dialogue with men at the community level aimed at changing their social perceptions of their female partners and of their responsibility for creating greater harmony in the home. 


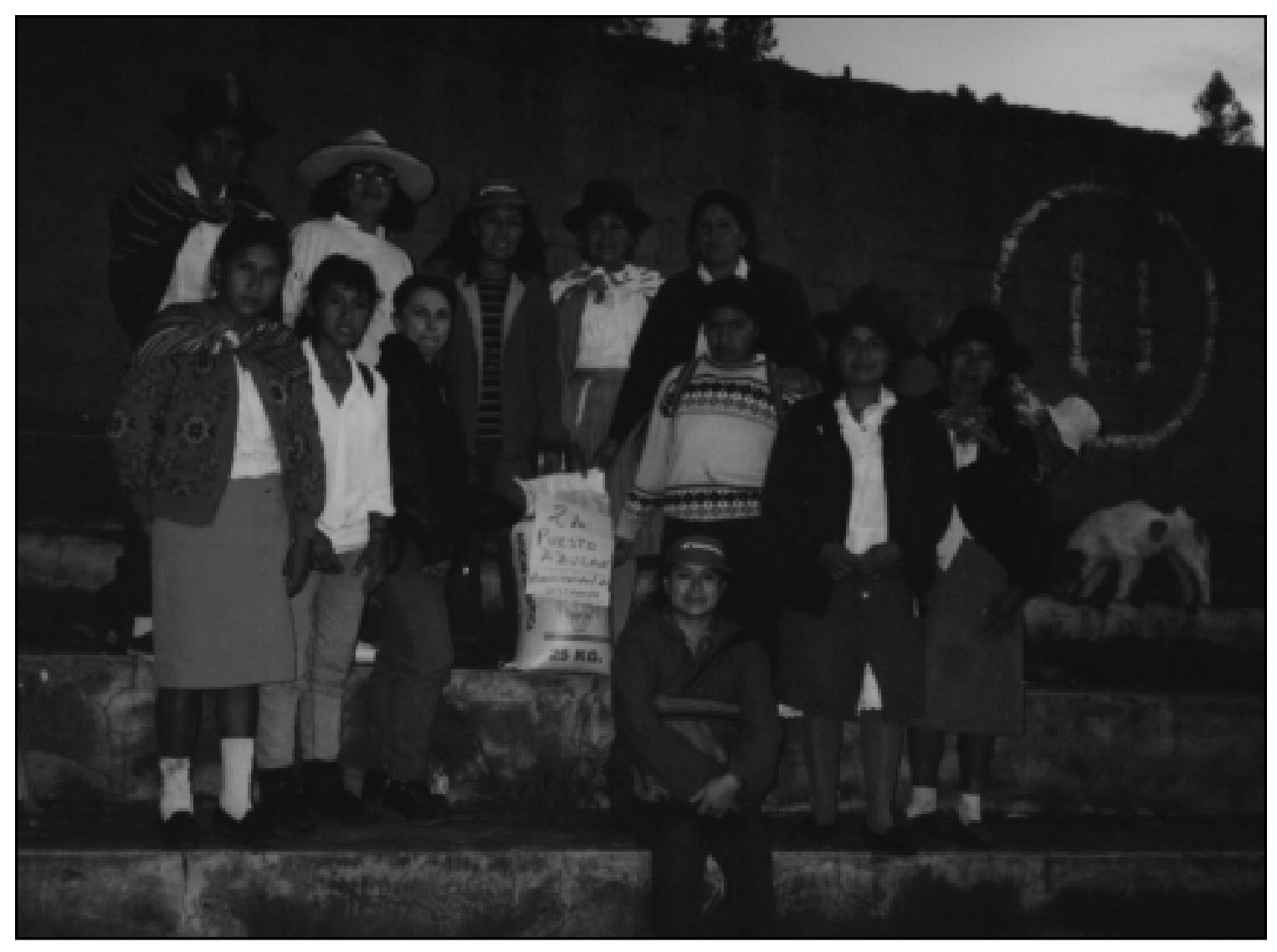

Seven years after its initiation, ReproSalud is poised to look critically at the results of its work so far. There are marked improvements in women's knowledge and health-seeking behavior, more supportive behaviors from the men in their lives, an increase in women's social and economic opportunities, and the development of accountability links between health services and their clientele.

Many of the debates prefiguring the ICPD in 1994 centered on whether contraceptives alone or development alone was the best approach to achieving voluntary fertility reduction in poor communities. Poor women, however, should not be asked to choose between reproductive health services and social and economic development- they need both. The Manuela Ramos Movement has shown us how to forge synergistic links between women's reproductive health and the social and economic domains of women's lives on a large scale. Support of large-scale projects such as ReproSalud and building capacity in organizations such as the Manuela Ramos Movement around the world can result in long-awaited and impressive gains in reducing unwanted fertility, along with achieving measurable outcomes in the health and social wellbeing of poor women. 


\section{Acknowledgment}

The author is indebted to Benno de Keijzer for providing the information used in the box "Gender and Health Workshops for Men," as well as much of the descriptive information about the development of the men's workshops.

\section{References}

Moyano, Jorge Reyes, Luis H. Ochoa, Vilma Sandoval F., Hans Raggers, and Shea Rutstein. 1997. Encuesta Demográfica y de Salud Familiar [Demographic study of family health]. Calverton, MD: DHS/ Macro International Inc.

Ravenholt, R.T. and John Chao. 1974. "Family planning programs: World fertility trends, 1974," Population Report, series J, no. 2, pp. J21-J39. Washington, DC: George Washington University Medical Center, Population Information Program.

ReproSalud. 1998. "Algunos resultados estadísticos de las entrevistas con promotoras y promotores" [Some statistical results from interviews with field staff], unpublished report.

Rogow, Deborah and Alejandro Diaz. 1999. "ReproSalud: Evaluation of project impact in the Chavin region: A case study," unpublished trip report to USAID/Lima and ReproSalud.
USAID. 1995. Project paper for USAID Project 527-0335, Reproductive Health in the Community (ReproSalud). Lima, Peru: United States Agency for International Development, Mimeo.

World Health Organization. 1998. Unsafe Abortion: Global and Regional Estimates of Incidence of and Mortality Due to Unsafe Abortion with a Listing of Available Country Data, 3rd ed. Document no. WHO/ RHT/MSM/97.16. Geneva: World Health Organization.

\section{Further Reading}

Andina, Michele, and Barbara Pillsbury. 1998. "Trust: An approach to women's empowerment: Lessons learned from an evaluation on empowerment and family planning with women's organizations," report. Los Angeles, CA: Pacific Institute for Women's Health.

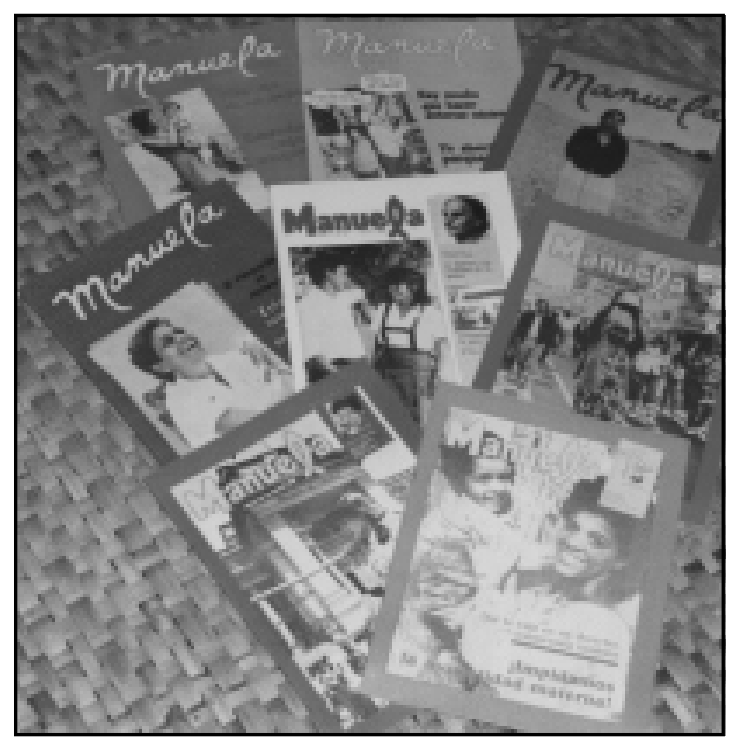




\section{Resumen en Español}

En los años 70 un grupo de siete mujeres limeñas se empezó a reunir para cuestionar los supuestos que definían su vida cotidiana. Al intuir que otras mujeres también podrían aprovechar la valoración y la formación de conciencia que estas conversaciones producían, el grupo organizó varios talleres en los que las mujeres podían reflexionar sobre sus propias vidas. Descubrieron que a pesar de las diferencias, todas las mujeres compartían inquietudes similares. Ya para 1980 el grupo había formado una ONG denominada Movimiento Manuela Ramos (MMR).

A medida que la crisis económica y política del Perú se profundizó en los años 80, el MMR reconoció que los problemas de las mujeres de los barrios pobres de Lima se multiplicaban a la misma vez que los servicios públicos empeoraban. Las Manuelas respondieron a este reto con la creación de una clínica de mujeres, un programa de servicios legales y, por último, un programa de generación de ingresos. En base a esta experiencia y un interés en las dimensiones políticas de la salud, el MMR se estableció como una voz importante en la comunidad peruana de planificación familiar.

Las Manuelas veían que la provisión de servicios estaba obstaculizada por la limitada movilidad social de las mujeres, su escaso poder de negociación, y su baja autoestima. Así, el MMR había empezado a perfeccionar varias estrategias para responder a esos desafíos. Justo en ese momento la misión de la USAID en Lima anunció una licitación que efectivamente aplicaría lo que se ha aprendido en el campo del desarrollo: que la participación comunitaria y el trabajo "desde abajo hacia arriba" deben ser el punto de partida. Aunque se sentían abrumadas por la magnitud del desafío, las Manuelas ganó la licitación. El nuevo proyecto, ReproSalud, es una de las raras ocasiones en que una ONG feminista ha juntado fuerzas con una entidad donante internacional como USAID.

El personal de ReproSalud utilizó encuestas y "talleres de diagnóstico" para recolectar información sobre los esquemas sociales de las mujeres, sus creencias religiosas, y sus principales necesidades e inquietudes (todo con un enfoque en salud reproductiva). En los talleres se le pedía a las mujeres que eligieran el aspecto de la salud reproductiva que fuera de mayor prioridad para ellas. Posteriormente ReproSalud escogía una organización de mujeres local para funcionar como socio en la atención al problema que se había identificado.
El proyecto había sido concebido exclusivamente para mujeres, pero este enfoque fue cuestionado casi de inmediato. Las mujeres en las comunidades dijeron que querían involucrar a sus maridos. Inicialmente el personal del proyecto se preocupó por la posibilidad de que se le quitaran recursos a las actividades para mujeres, pero al poco tiempo decidieron modificar el diseño según las demandas de las mujeres.

Uno de los desafíos importantes en un proyecto como ReproSalud es cómo evaluar sus actividades. Aunque el diseño del proyecto responde al sentido común, estudiar su impacto resulta ser una tarea compleja. Al final de cuentas, al proyecto se lo juzgará según el éxito que tenga en fomentar un comportamiento que promueve salud y la utilización de servicios (incluso los de planificación familiar). Pero teniendo en cuenta que se requieren varios pasos para que una mujer tome control de su propia salud reproductiva, se decidió evaluar el éxito del proyecto en base a ciertos hitos interinos. Estos pueden ser el potenciamiento de la mujer como individuo (mejoras en la autoestima, control sobre el dinero, conciencia de sus derechos, conocimiento de/ comodidad con su cuerpo); el potenciamiento de la mujer dentro de su familia (reducción en la violencia familiar, satisfacción en la vida sexual y en la vida familiar en general); y la capacidad de la mujer de propiciar su propia salud reproductiva. Hasta la fecha se han registrado cambios positivos en cada uno de estos tres indicadores.

La experiencia de este proyecto conjunto del MMR y USAID demuestra que este tipo de cooperación puede tener éxito, y además ofrece varias lecciones. (1) Aunque el MMR era pequeño, había acumulado experiencia en casi todas las actividades requeridas por el proyecto; (2) Las Manuelas poblaron el equipo directivo de ReproSalud con mujeres que ya estaban en el Movimiento, lo cual aseguró unidad y el apoyo del resto de la organización; (3) USAID proporcionó apoyo técnico y profesional a las Manuelas; (4) El aspecto más importante del proyecto fue la claridad de sus propósitos; (5) Sólo un proyecto flexible es capaz de escuchar a las mujeres; (6) Varios elementos programáticos fueron fundamentales para el éxito: la inclusión de hombres, el fortalecimiento de la autoestima y la acción colectiva parecen haber sido especialmente importantes. 


\section{Résumé en Français}

A la fin des années 70, un groupe de sept femmes à Lima a commencé à se rencontrer pour voir sous une nouvelle lumière leur vie de tous les jours: quelles étaient leurs réalités et que souhaitaient-elles? Animé par le sentiment que chaque femme apprécierait cette validation et prise de conscience, le groupe a organisé un atelier permettant aux femmes de réfléchir à leur existence. Le groupe a constaté que les femmes partagent les mêmes problèmes et préoccupations. En 1980, le groupe fondait une ONG, choisissant le nom de Movimiento Manuela Ramos (MMR).

Alors que la crise économique et politique au Pérou prenait des proportions de plus en plus graves pendant les années 80 , le MMR a reconnu que les femmes des taudis de Lima se heurtaient à des problèmes de plus en plus préoccupants en même temps que s'amenuisaient les services publics qui leur étaient fournis. Face à cette situation, les Manuelas tel qu'elles avaient commencé à s'appeler ont créé un dispensaire pour les femmes, un programme de services juridiques aidant ces dernières et elles ont mis sur pied un petit projet aux femmes de gagner de l'argent. S'inspirant de son expérience concernant la réalisation de programmes et de l'intérêt qu'il portait aux questions de politiques prises dans un sens plus large, le MMR s'est déclaré partie prenante au sein de la communauté de planification familiale du Pérou.

Les défenseurs et les professionnels de la santé de la femme savaient depuis longtemps que la prestation de services était entravée par la mobilité sociale limitée des femmes, leur pouvoir de négociation restreint et la faible estime qu'elles avaient d'elles-mêmes. Mais de fait les Manuelas avaient commencé à s'attaquer à ces problèmes et leurs méthodes réussissaient. Aidé par l'arrivée d'un personnel sensible à la question à la mission USAID à Lima, un appel d'offres d'un caractère unique a été lancé cherchant à atteindre des femmes dans les régions les plus pauvres du Pérou. Les Manuelas ont présenté une soumission pour un projet appelé ReproSalud et leur contrat a été adjugé. ReproSalud est l'une des rares fois où une ONG féministe s'alliait à un important bailleur de fonds international pour mettre en œuvre un programme de grande envergure.

Le personnel de ReproSalud a utilisé des enquêtes individuelles et des «ateliers de diagnostic» d'un caractère participatif pour réunir des informations sur les modes sociaux, les systèmes de croyances et les principales préoccupations des femmes (surtout en ce qui concerne la santé reproductive). On a demandé aux femmes locales participant aux ateliers d'indiquer quel était le problème prioritaire sur le plan de la santé repro- ductive. Ensuite, ReproSalud a choisi un groupement féminin local qui allait devenir le partenaire des efforts faits pour lutter contre le problème identifié. Les problèmes prioritaires étaient les suivants: infections du tractus génital, grossesse non souhaitée et complications liés à l'accouchement. Le projet avait été conçu en ciblant uniquement les femmes mais cette notion a été rejetée de suite. En effet, les femmes de la communauté souhaitaient que leur mari participe et le personnel du projet a modifié la conception en réponse aux demandes des femmes.

Pour un projet comme ReproSalud, il se pose une question importante: comment évaluer ses activités et efforts. Malgré une conception des plus logiques, les complexités liées à l'étude de son impact ne sont pas des moindres. En dernière analyse, le projet sera jugé à l'aune de sa réussite en ce qui concerne la promotion du comportement favorisant la santé et l'utilisation des services. Mais au regard des étapes que doivent emprunter les femmes pour prendre en main leur propre santé reproductive, le projet cherche à évaluer la réussite rencontrée à des jalons intérimaires, par exemple, l'autonomie et l'habilitation des femmes en tant qu'individus (meilleure estime d'elle-même, davantage de contrôle sur l'argent, connaissance de leurs droits, connaissance de leur propre corps); leur position au sein de la famille (notamment les changements au niveau de la violence conjugale et une vie sexuelle et familiale satisfaisante); la capacité des femmes à promouvoir leur propre santé reproductive (évaluée par le biais des comportements de promotion de la santé adoptés à la maison, l'utilisation des services et l'interaction efficace avec les prestataires de la santé). Des changements positifs ont été notés pour tous les trois types d'indicateurs. L'histoire finale de ReproSalud est loin d'être écrite. L'expérience du travail conjoint entre le MMR et l'USAID montre non seulement qu'une telle collaboration est possible mais dégage également des leçons vitales. (1) Le MMR était petit mais comptait pourtant une expérience portant sur pratiquement tous les aspects du projet; (2) Les Manuelas avaient mis à la tête du projet leur propre personnel, assurant ainsi une bonne cohésion et une bonne solidarité avec le reste de l'organisation; (3) L'USAID a fourni un soutien technique et professionnel aux Manuelas; (4) Un but bien clair représentait la partie la plus importante de ce projet; (5) Le projet doit faire preuve de souplesse pour prêter l'oreille aux demandes des femmes; (6) Un certain nombre d'éléments programmatiques sont essentiels pour garantir la réussite: faire participer les hommes, renforcer l'estime de soi-même et prendre une action collective. 
